\title{
ESTUDO DA EFICIÊNCIA DE ALGUNS POLIELETRÔLITOS UTILIZADOS NA CLARIFICAC,ĀO DO CALDO DE CANA
}

\author{
JuAREZ DE Souza \\ Químico Industrial
}

Orientador: Prof. Dr. ENIO ROQUE DE OLIVEIRA

Dissertação apresentada à Escola Superior de Agricultura "Luiz de Queiroz", da Universida de de São Paulo, para obtenção do título de Mestre em Agronomia, Área de Concentração: Tecnologia de Alimentos.

\section{PIRACICABA}

Estado de São Paulo - Brasil 
.ii.

A

Maria Mery Banho

Celia Regina B. Mattos

DEDICO •

A.

Aziul Alves do Banho

Nilda Rosa de Souza

(in memoriam)

OFEREÇO . 


\section{AGRADECIMENTOS}

Ao Prof. Dr. Enio Roque de Oliveira, pelo incentivo e pela valiosa orientação para a elaboração e desenvolvi mento deste trabalho.

Aos Profs. Dr. Antonio Joaquim de Oliveira, $\mathrm{Dr}$. Paulo Cantare11i e Dr. José Paulo Stupie11o, pelo apoio e estímulo de sempre, além das importantes sugestões.

Ao Prof. Clóvis Pompilio de Abreu e ao Eng Norber to Lavorenti, pelo planejamento e orientação prestados ao tratamento estatístico dos resultados experimentais.

As Bibliotecárias Maria Aparecida P. Remédio, Beatriz H. Giongo e Midian Gustinelli, pelo auxílio na obten ção do material bibliográfico e organização da literatura.

As seguintes empresas pelo fornecimento das amostras de polieletrôlitos utilizadas nesta pesquisa:

- AquATEC Quimica S.A.

- BASF BRASILEIRA S.A.

- DOW PRODUTOS QUIMICOS

- HENKEL S.A. INDUSTRIAS QUIMICAS 
Aos Eng 9 . Pedro S. Katayama e Claudio H. Lopes, pe 1o apoio constante, estímulo e sugestões oportunas.

Ao Prof. Mário Farinazzo Filho, pelo incansável es tímulo.

Aos Técnicos Químicos Joseval Habermann, Regina B. Lordelo e Arquimedes 0. Yamagushi, pelo auxílio no desenvo 1 vimento da parte analítica.

Aos Técnicos da Usina Costa Pinto, Mário Mazza e Claudio Berreta, pelo auxílio nos trabalhos realizados na Usina Costa Pinto e pelas informações prestadas.

Aos Diretores da Usina Costa Pinto, pelo fornecimento de materiais importantes ao desenvolvimento deste tra balho.

A todos aqueles que contribuiram, direta ou indire tamente, para que esse trabalho se realizasse, os mais sin ceros agradecimentos do autor. 


\section{ÍNDICE}

pảgina

RESUMO

viii

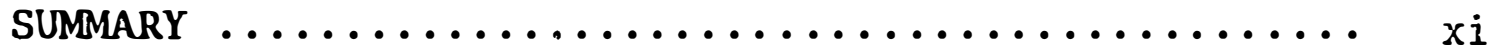

1. INTRODUÇAOO $\ldots \ldots \ldots \ldots \ldots \ldots \ldots \ldots \ldots \ldots \ldots \ldots \ldots \ldots \ldots \ldots$

2. REVISÃO BIBLIOGRAFICA $\ldots \ldots \ldots \ldots \ldots \ldots \ldots \ldots \ldots \ldots$

2.1. Clarificação $\ldots \ldots \ldots \ldots \ldots \ldots \ldots \ldots \ldots \ldots \ldots \ldots$

2.1.1. Caleagem .................. 9

2.1.2. Sulfitação ................. 12

2.1.3. Aspectos físicos e químicos dos modelos de clarificação .............. 14

2.2. Condições de Processo, Temperatura e pH .... 16

2.3. Caldo de Cana ..................... 18

2.3.1. Alguns componentes do caldo e suas implicações a nível de processamento.. 25

2.4. Polieletrólitos ................. 28

2.4.1. Características gerais dos polieletrólitos ................... 28 
pāgina

2.4.2. Mecanismo de funcionamento doṣ po-

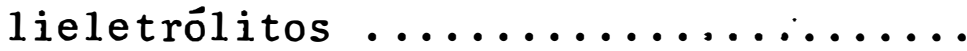

2.4.3. Aplicaçōes, industriais dos poliele trólitos na clarificação do caldo de cana $\ldots \ldots \ldots \ldots \ldots \ldots \ldots \ldots \ldots$

3. MATERIAIS E METODOS $\ldots \ldots \ldots \ldots \ldots \ldots \ldots \ldots \ldots \ldots, 48$

3.1. Material ...................... 49

3.1.1. Caldo de cana ................. 49

3.1.2. Decantador de laboratório e provetas.. 49

3.1.3. Leite de cal ................. 52

3.1.4. Acido sulfuroso $\ldots \ldots \ldots \ldots \ldots \ldots \ldots .52$

3.1.5. Polieletrólitos ................. 52

3.2. Mêtodos $\ldots \ldots \ldots \ldots \ldots \ldots \ldots \ldots \ldots \ldots \ldots . \ldots \ldots$

3.2.1. Métodos tecnológicos ............ 53

3.2.2. Métodos analíticos ............. 54

3.2.3. Cálculos tecnológicos ............ 56

3.2.4. Métodos estatísticos ........... 56

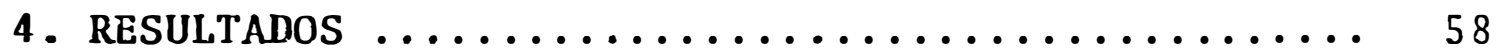

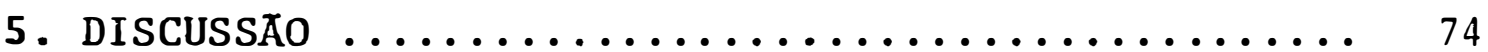

5.1. Caldo Sulfitado e Caleado .............. 74

5.2. Caldo Caleado ..................... 80 
.vii.

pāgina

6. DISCUSSOES FINAIS ....................... 85

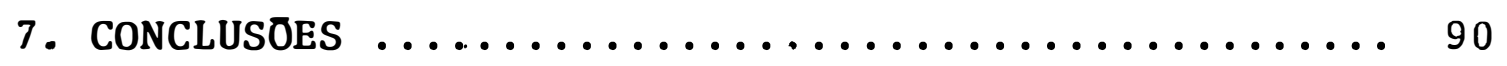

8. REFERENCIAS BIBLIOGRÁFICAS ................ 92 
-viii.

\title{
ESTUDO DA EFICIÊNCIA DE ALGUNS POLIELETRÓLITOS UTILIZADOS NA CLARIFICAÇĀO DO CALDO DE CANA
}

\author{
Autor: Juarez de Souza \\ Orientador: Prof. Dr. Enio Roque de Oliveira
}

\section{RESUMO}

O direcionamento deste trabalho objetivou bus car respostas sobre a atuação e o comportamento dos polieletrólitos como auxiliares de clarificação do caldo de cana na produção de açưcar, dando um tratamento voltado para a $\underline{\text { a }}$ nảlise comparativa entre as eficiências de alguns desses produtos oferecidos no comércio.

0 estudo enfocou seis desses polímeros, gen tilmente cedidos pelos seus respectivos fabricantes e acompanhados das instruçōes de uso que foram seguidas integra mente. O caldo de cana e o leite de cal a $10^{\circ}$ Beaumé foram coletados em uma usina da região de Piracicaha, Estado de São Paulo.

A anālise comparativa entre os comportamentos foi feita tanto para a situação do caldo caleado como também para o caldo sulfitado. Procurou-se seguir as condições 
. $\mathrm{ix}$.

de processo das usinas no geral, tanto a nível de $\mathrm{pH}$ como de temperatura na condução do fenômeno de decantação.

0 ensaio, por sua vez, foi desenvolvido ao longo da safra açucareira de 1986. O quadro analítico, que serviu como referencial de eficiencia, constou dos parâmetros brix, pol, cinzas, pH, cor e turbidez. Também foram calculadas a pureza aparente e a $\frac{o}{o}$ de borra.

A matriz estatística evidenciou principalmen te as conclusões seguintes:

a) Os polieletrôlitos mostram ser, mesmo de forma modesta em certos casos, auxiliares de clarificação $\underline{e}$ ficientes.

b) Não se verificou entre os polieletrólitos diferenças significativas de eficiência dentro das concentrações utilizadas.

c) Entre as concentrações dentro de cada po lieletrólito, a correspondente a 4 ppm apareceu com maior $\underline{e}$ ficácia.

d) No geral, os polímeros se mostraram melhor do que a testemunha nos indices mais importantes segunco a literatura, que são o índice de cor e a $:$ de borra decantzda. ej Ficou patente, tambëm, através da literatura e dos testes realizados, que o perfil delineado tem tendência muito maior à particularização de cada caso do que à generalização, ou seja, devido aos detalhes intrínse- 
cos relativos a variedades de matêria-prima e coridições de processamento, os resultados podem ou não serem repetitivos em fábricas diferentes. 
.$x i$.

\title{
EFFICIENCY STUDY OF SOME POLYELECTROLYTES USED FOR SUGAR-CANE CLARIFICATION
}

\author{
Author : Juarez de Souza \\ Adviser: Prof. Dr. Enio Roque de Oliveira
}

\section{SUMMARY}

The objective of this study was to seek answers as to the polyelectrolyte actuation and behavior as sugar-cane juice clarification auxiliary for sugar production, focusing on comparative analyses between the efficiencies of some commercially-available products.

This study comprised six polymers, kindly granted by their manufacturers along with the user's instructions, which were carefully observed.

The sugar-cane juice and the $1 \mathrm{ime}$ milk at $10^{\circ}$ Beaumé were collected at a sugar-mill in Piracicaba, São Pau lo State.

The comparative analyses of behavior were per formed both for limed juice and sulphited juice. The sugar-mill general process conditions were folowed, regarding $\mathrm{pH}$ and temperature, when effecting the decantation phenomenon. 
.xii .

The experience was developed during the 1986 sugar-cane harvest season. The analytical frame, which was taken as the efficiency reference, comprised the following parameters: brix, pol, ashes, pH, color and turbidity. The apparent purity and the sediment: were also computed.

The statistical matrix allowed the following main conclusions:

a) The polyelectrolytes appeared to be, al though modestly in some instances, efficient clarification auxilia ries.

b) No significant efficiency. differences between the polyelectrolytes were observed in the concen tration ranges used.

c) Within the concentration ranges tested for each polyelectrolyte, the concentration corresponding to $4 \mathrm{ppm}$ appeared to be the most efficient.

d) In general the polymers appeared to be better than the witness in the most importantindicators according to literature, which are color and decanted sediment $:$

e) It was also established, both from litera ture and the tests performed, that the outlined profile tends much more to particularization than to generalization in each case, that is, because of the intrinsical details regarding raw-material varieties and process conditions, the results can be repetitive or not in different sugar-mills. 


\section{INTRODUÇÃO}

Nas operações industriais para a fabricação do açưcar, a etapa de clarificação do caldo é decisória pa ra a qualidade do produto final. Se bem conduzida, aumenta significativamente as oportunidades de atender com larga margem as especificações exigidas. Em caso contrārio, compromete de maneira negativa não apenas o açúcar pronto para o consumo, mas também as etapas de fabricação em diversos segmentos, tais como a deformação de estrutura e o escurecí mento do cristal, efeito catalizador de atividade microbiana, incrustações. em evaporadores e cozedores que acarreta riam maior consumo de combustível, onerando ainda mais o processo fabril.

No Brasil, o setor técnico-açucareiro tem re servado parte de sua atenção para os problemas pertinentes à fase de clarificação, enfocando não apenas a questão sob um ponto de vista genérico, mas também trazendo à tona para discussões, problemas atípicos, particulares de uma determi nada unidade produtora, além de tentar introduzir otimizações nesta etapa da produção.

Esta postura evidencia a preocupação e a necessidade de se dar continuidade à compatibilização da pos $\underline{i}$ 
ção de grande exportador mundial, com a qualidade do prodụ to oferecido.

A questão, então, seria como se aproximar, ao máximo, do ponto ideal de purificação de uma substância tão complexa como o caldo de cana.

De maneira geral, a literatura sobre o assun to mostra praticamente as mesmas faixas de quantificação dos seus componentes, evidenciando a complexidade da matéria.

Este líquido, algo viscoso, caracteristicamente ácido, tem justificado as variações dos teores quantí tativos de seus componentes, por ser fruto do contexto bio lógico de um ser vivo, que é a cana-de-açūcar. E este contexto é passível de sensíveis mudanças, dependendo da varie dade da cana, tipo de adubo recebido durante o plantio, fatores climáticos, idade, solo e sanidade. Por outro lado, sob uma ótica qualitativa, embora grande parte dos componen tes apresentados forme uma família heterogênea indesejável dentro da usina devido aos inúmeros transtornos que trazem para dentro do processo fabril, é fundamental que eles exis tam de forna bem balanceada na cana, quando em sua vida no campo, pois o ser vivo cana-de-açúcar também tem seus compromissos de ordem fisiológica, a nível de biossíntese, me tabolismo e desenvolvimento. E aí são vitais as funções de senvolvidas por ácidos orgânicos, aminoácidos, proteínas, lipídeos, não-açúcares inorgânicos, etc... 
Entretanto na fábrica, esses componentes pas sam a ser grupos indesejáveis juntamente com impurezas de outras origens, que podem advir de terras e sujeiras oriundas de canas mal lavadas antes de seren: encaminhadas ao pre paro, ou de partículas geradas pelos desgastes dos próprios equipamentos de produção.

Existem, portanto, segmentos distintos que contribuem para a complexidade do caldo entrante na fábrica e somente uma clarificação bem conduzida poderá descartar grande parte destes compostos, absolvendo a. usina da penali dade do aumento desnecessário do custo de produção, além da obtenção de um produto final de qualidade comprometedora.

No geral, a clarificação teria por meta remo ver do caldo o máximo de impurezas dissolvidas e em suspen são.

Examinando o parque açucareiro da região cen tro-sul, o maior do Brasil, nota-se que basicamente predomi nam três modelos de clarificação. Com maior frequência encontra-se:

- defecação, utilizando ap̣enas cal;

- sulfitação, onde há adirão de cal e dióxido de enxofre;

- fosfatação, utilizando-se, além da cal, o ácido fosfórico.

Entretanto, a escolha da matriz de clarifica ção ideal passa a ser função das particularidades indus- 
triais e de matéria-prima de cada fábrica.

Objetivando buscar maior eficiência e rendimento nesta etapa importantíssima do processo., foram apare cendo nas ûltimas décadas, no histórico de desenvolvimento desta técnica, os chamados auxiliares de clarificação.

No Brasil, encontram-se neste grupo a bentonita, que é uma rocha composta de uma argila, a montmorilo nita, o óxido de magnésio e principalmente com maior frequência de uso os chamados polieletrólitos, objeto princí pal deste trabalho.

Os polieletrólitos são polímeros sintéticos, solúveis em água, que de forma geral se apresentam na forma sólida (em pó), em solução ou em emulsão. São aplicados em soluções diluídas ao caldo quente e alcalinizado e estas so 1 uções são de aspecto incolor, viscoso e insignificante po tencial corrosivo.

A nível de estrutura molecular podem se apre sentar nas formas catiônica, aniônica ou não-iônica, varian do. consideravelmente em termos de pesos moleculares, cuja ờdem de grandeza está em torno de 10 milhões. São produzí dos principalmente por polimerização de acrilamidas e outros monômeros, gerando as poliacrilamidas, que possuem basicamente o seguinte arranjo estrutural:

$$
\left[\begin{array}{cc}
-\mathrm{CH}_{2}- & \mathrm{CH}- \\
& \mathrm{I}=0 \\
& \mathrm{I} \\
& \mathrm{NH}_{2}
\end{array}\right] \cdot \mathrm{n}
$$


Em termos industriais, sob uma ótica global, as linhas de polieletrólitos foram muito diversificadas, en contrando-se hoje no mercado ramificações que atendem a várias aplicações industriais, tais como tratamento de águas, refino de óleo industrial, setor metalúrgico, recuperação de urânio, indústria de papel, fabricação de ácido fosfórí co, produção de sulfato de alumínio, etc...

$\mathrm{Na}$ indústria açucareira, o seu uso começou a ser incrementado na década de 1950. Este tipo de tratamento obteve maior difusão nas usinas do Havaí.

A sua aplicação tem sido recomendada não ape nas como reagente adicional na fase de clarificação, mas tam bém particularmente quando a presença de colóides se apresenta de forma problemática no caldo.

As evoluções têm variado principalmente com a natureza dos componentes não-açúcar existentes no caldo bruto. Payne e Sioane, citados por JENKINS (1966), comentam que a ação destes reagentes é em certas situações duvidosa, e afirmam que polieletrólitos do tipo catiônico devem, provavelmente, apresentar mais efetividade do que o tipo aniô nico, visto que a maioria das partículas coloidais no caldo possui carga negativa.

Com base nas circunstâncias apresentadas, propôs-se um trabalho que tem por meta realizar um estudo com os seguintes objetivos: 
- Avaliar, de forma global e comparativa, a eficiência de alguns polieletrôlitos utilizados na indústria açucareira brasileira, como auxiliares de clarificação do caldo.

- Promover, através de matriz estatística adequada, um tra tamento que evidencie o comportamento de cada parâmetro a nalisado em função de cada polieletrólito utilizado.

- Contribuir para formar um cabedal de informaçõ்es sobre o assunto, que poderá oportunamente vir a subsidiar tecnica mente as indústrias açucareiras. 


\section{REVISÃO BIBLIOGRÁFICA}

\subsection{Clarifi cação}

0 reportamento histórico da fabricação do àçúcar evidencia toda uma atenção rigorosa para a etapa de clarificação do caldo de cana.

Determinantemente esta passa a ser uma fase que assumirá grande parcela de responsabilidade sobre a qua lidade do produto final.

Neste contexto, devem atuar com a máxima efí cácia possível, os mecanismos de clarificação para que o cal. do em processo a partir daí, seja respaldado tecnicamente por um alto grau de pureza.

Para SPENCER e MEADE (1967), o objetivo primordial da clarificação é eliminar a quantidade máxima de impurezas do caldo, tão pronto como o permitam outras consi derações, tais como a limpidez e a reação do caldo claro. OLIVEIRA (1979) faz a colocação de que a purificação visa a obtenção de um caldo claro, límpido e brilhante, mediante a coagulação máxima de colóides e a formação de precipitados que absorvame arrastem as impurezas coloidais. Os processos não podem provocar a inversão da sacarose, de $\underline{s}$ 
truição dos açúcares redutores e diminuição da pureza do caldo.

A lógica do fenômeno de decantação é uma con sequência de princípios físico-químicos. MOSPAN et alii (1984) propuseram um modelo matemático derivado da equação de Stokes, que é largamente usada na representação da hidro dinâmica das partîculas. Os fundamentos, como não poderiam deixar de ser, são alicerçados no equacionamento dos parâme tros velocidade de sedimentação, diâmetro da partícula, den sidade do líquido, viscosidade do líquido, densidade do ma terial da partícula e aceleração da gravidade.

BERGER (1976) faz considerações sob este as pecto, imbutindo também a importância dos fenômenos de superfície das partículas. O autor afirma que partículas que teriam atividade na superfície, esta atividade se concentra ria na interface tanto em um sistema líquido-gâs, como em um sistema sólido-líquido, como é no caso do caldo de cana. No caso das moléculas de superfície, existirâ uma força de desbalanceamento exercendo uma atração com tendências a "pu xar" as moléculas vizinhas para si, estabelecendo uma tensão de magnitude variâvel, que também é função da temperatu ra.

Ainda BERGER (1976), mostra sob este aspecto outras considerações que podem vir a influenciar a hidrodi nâmica da partícula e por conseguinte a decantação, tais 
como a tensão de superfície que correlaciona de forma biun $\underline{i}$ voca as grandezas superfície e volume, a visçosidade da superfície, o potencial eletrocinético e a situação termodinâa mica envolvendo entropia, volume, temperatura e pressão. To dos esses parâmetros estariam voltados para sustentar na te oria da hidrodinâmica a ocorrência da decantação de uma maneira geral.

Por outro lado, particularizando o fenômeno para a indústria açucareira, mais especificamente na fase de clarificação, existe toda uma conceituação regida por es ses princípios na forma dos conhecidos modelos de clarifica ção.

No Brasil predominam basicamente dois modelos de clarificação. O primeiro seria a caleagem, que é mui to utilizada na produção do açūcar bruto para exportação. 0 outro seria a sulfitação, mais empregada na fabricação do a çücar branco.

Sobre estes dois segmentos, caleagem e sulf $\underline{i}$ tação, cabem algumas consideraçōes:

\subsubsection{CALEAGEM}

JENKINS (1966) afirma que já no século deze nove os egípcios, em suas primitivas indústrias açucareiras, utilizavam a cal como agente clarificante. HONIG (1969) de $\underline{s}$ 
creve como ser a técnica mais antiga existente na literatú ra sobre a fabricação de açūcar.

Basicamente consiste, dinamizada pelo aqueci mento, em provocar reaçōes no meio, dando como efeito a aglutinação de partículas centralizadas pelo produto formado da reação que, com o aumento de peso e a ligeira diminuição da densidade do meio provocada pelo aquecimento, tendem a precipitar. 0 fenômeno, entre outras coisas, é função da concentração iônica do meio, pois os colóides necessitam de uma determinada concentração capaz de neutralizar sua carga elétrica, que seria o seu ponto isoelétrico.

De maneira geral, o decantado é composto de uma mistura heterogênea com maiores proporçôes de material graxo, silicatos, sesquióxidos, matéria proteica, fosfatos e sulfatos. A operação é determinada para interagir no caldo na faixa de $\mathrm{pH}$ em torno da neutralidade, onde se encon traria o ponto isoelétrico da maioria dos colóides.

0 modelo reacional da formação do principal composto nesta etapa se desenvolve basicamente em dois pas sos. Primeiramente, sendo o hidróxido de cálcio uma base de metal bivalente, a dissociação acontece da seguinte forma:

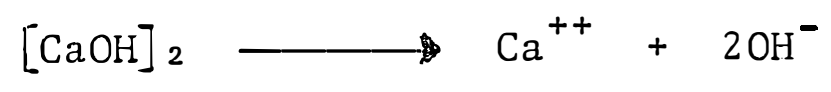


0 passo conclusivo seria para a formação do principal composto produzido na caleagem e que seria o res ponsāvel maior pela centralização das aglutinações colo dais. Isto acontece através da reação com o fósforo presente no caldo, que é um componente de importância destacada rı clarificação.

$$
\mathrm{Ca}^{++}+\mathrm{HPO}_{4}^{-} \longrightarrow \mathrm{CaHPO}_{4}
$$

ZARRALUQUI et alii (1984) postulam ainda sobre este sistema, que as concentraçōes de fósforo e cálcio são altamente significativas na remoção de substâncias coloidalmente dispersas e que também a temperatura é de relevável importância. Entretanto, uma ūltima consideração fei ta por esses autores estabelece que a dependência da remoção de substâncias corantes em função da concentração de fosfato e hidrôxido de cálcio não é linear e cumpre uma fun ção do tipo $y=a+b x^{1} \backslash^{2}$, onde $y$ é o percentual de remoção da cor, a e b constantes que dependerão das características da matēria-prima. A esse respeito, sabe-se que as equações de correlazão dessus grandezas dependem de uma gama enorme de fatores variáveis e, portanto, elas tendem muito mais a uma ou a vārias expressões matemáticas variāveis, desconhe cidas e indeterminadas, principalmente quando vistas sob a ôtica da dinâmica fabril. 
EL KADER (1983) ressalta a importância do processo da caleagem e atribui o sucesso deste principalmen te à efetividade da interação dos colóides de cargas opostas.

Sob a mesma teoria, ZUMALACARREGUI (1984) ra tifica o princípio da neutralidade, onde o número total de moles de cargas positivas em solução é igual ao de cargas negativas, ou seja, o autor expressa que:

$$
\begin{gathered}
2\left[\mathrm{Mg}^{++}\right]+\left[\mathrm{Na}^{+}\right]+\left[\mathrm{K}^{+}\right]+2\left[\mathrm{Ca}^{++}\right]+\left[\mathrm{H}^{+}\right]=\left[\mathrm{Cl}^{-}\right]+\left[\mathrm{OH}^{-}\right]+[\text {EAconitato }] \\
+\left[\Sigma \mathrm{PO}_{4}\right]+\left[\mathrm{H}_{3} \mathrm{SiO}_{4}\right]
\end{gathered}
$$

e ainda, à medida que a alcalinização vai ocorrendo, através da caleagem, a concentração das espécies em solução vai diminuindo e o conteúdo de cada espécie no precipitado vai aumentando.

\subsubsection{SULFI TAÇÃO}

0 enxofre pode ser considerado como um dos $\underline{\mathrm{a}}$ gentes químicos mais importantes da indústria açucareira pe la eficácia de sua acuação no processo de clarificação.

Em atuação conjunta com a cal, hã a formação do sulfito de cálcio, que funciona como um centro aglutinador de substâncias indesejáveis ao processo. O efeito, a ní vel reacional, pode ser resumido da seguinte forma: 


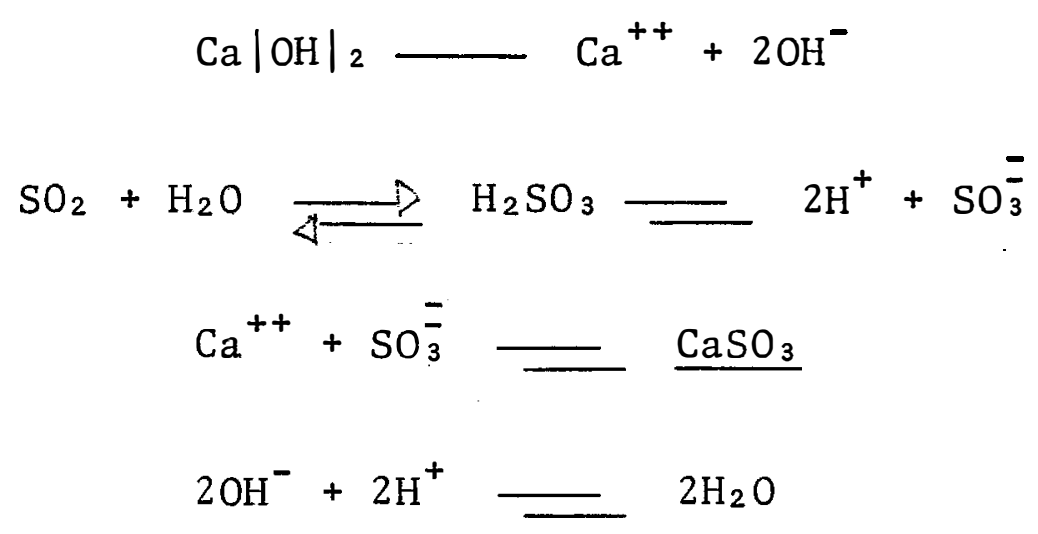

Maxwe11, citado por HONIG (1969), comenta que a prätica desta técnica teve início na Europa e seu uso obteve grande expansão e incentivo nas ilhas Mauricio por vol ta de 1865 .

Os primeiros trabalhos publicados a respeito datam de 1905, segundo MARCHES (1969). Mas foi a partir de 1926 que o processo começou a passar por significativas ot $\underline{i}$ mizações, onde se davam mais importância à medição de pH e à circulação da massa líquida nos recipientes de reação.

A presença de sua característica redutora pre vinirā, ou pelo menos minimizará, a formação de cor nas ủltimas etapas da fabricação, além de contribuir para a dimi nuição da viscosidade da massa líquida en processo.

KOZIAVKIN et alii (1983) consideram que a ação de descoloração da sulfitação é o efeito da transforma ção dos grupamentos cromóforos em incolores promovida pelo bloqueio dos grupos carbonílicos que participam nas reações de formação das substâncias corantes. Fundamentalmente, a des 
coloração ocorre em soluções nas quais estão substâncias mo lecularmente dispersas.

\subsubsection{ASPECTOS FÍSICOS E QUÍMICOS DOS MODELOS DE CLARI FI CAÇÃO}

Quando se aciona o mecanismo que desencadeia as reações de clarificação, em verdade estariam se criando, através dos principais produtos formados nessas reações, su perfícies coloidais carregadas positivamente envolvendo for ças eletrocinéticas. E serão estas forças que irão atrair e neutralizar as partículas originariamente carregadas negati vamente, provocando um aumento de volume na estrutura dos flocos formados como resultado desta interação e, por conse guinte, forçando a efetivação da decantação.

As partículas envolvidas no sistema caldo de cana seriam regidas a nível de estabilidade por forças de $\underline{\text { a }}$ tração conhecidas como forças de Van der Walls e forças repulsivas representadas por potencial zeta.

Segundo RAHA (1977), as partículas carregadas do caldo após coagulação inicial, retêm algumas cargas sobre a superfície externa de agregados primärios e tenderão a aglutinar por combinação com outras partículas carregadas atê elas decantarem por forças de estabilização dos flocos. Estes terão uma certa quantidade de força mecânica e serão 
capazes de manter suas identidades através de forças medianas e colisões ocorridas durante a decantação na fábrica.

A estrutura final do floco dependerá da forma dos agregados primários e da posição das áreas carrega das.

Por outro lado, as partículas de fosfato de cālcio e sulfito de cālcio, principais produtos formados na técnica da clarificação, quando no agregado primário fican parcialmente cobertas por moléculas de proteínas, então as cargas na superfície do agregado primārio serão negativas e estas cargas negativas aglutinarão mais partículas de fosfa to de cálcio e sulfito de cálcio nas suas superfícies exter nas. Estas, carregadas positivamente, atuarão então como pon tes para aglutinação de camadas do agregado primário juntan do-as progressivamente como sob efeito de um empacotamento. Uma vez provocada a decantação de uma dada suspensão concen trada, cada camada da partícula deslocará continuamente o líquido abaixo. Se o volume de uma determinada concentração de sólido em determinada camada é C, o espaço livre por uni dade de volume é $[1-C]=\varepsilon$. E se $\mathbf{V}$ é a taxa observada de de cantação dos sólidos, então CV, o volume do líquido removido por partículas decantadas, seguiria percorrendo uma área disponível com uma velocidade $\frac{\mathrm{CV}}{\varepsilon}$. Assim, a equação da taxa de decantação, segundo RAHA (1977), pode ser assim es crita $V s=V+\frac{C V}{\varepsilon}$, onde $V s$ é a velocidade de decanta 
ção de Stokes.

0 modelo é bem sustentado para a trajetória do fluxo diretamente retilínea. Entretanto, o caminho percorrido ê relativamente longo, e a equação poderia ser equi librada com a introdução do fator de sinuosidade (Lp), que seria expresso como:

$$
\mathrm{Lp}=\frac{\text { Comprimento do caminho efetivo a ser seguido }}{\text { Comprimento do caminho em linha reta }}
$$

o que permitiria escrever a equação da decantação assim:

$$
\mathrm{V}=\mathrm{Vs}-\frac{\mathrm{CV}}{\varepsilon} \mathrm{Lp}
$$

Entretanto, o modelo preconizado assume gran dezạs variáveis, uma vez que, segundo MOSPAN et alii (1984), ele é tremendamente influenciado atravês da variaçâo de características da matéria-prima.

\subsection{Condições de Processo, Temperatura e pH}

Os principais parâmetros induzidos na clarificação seriam principalmente $\mathrm{pH}$ e temperatura.

A introdução do controle do $\mathrm{pH}$, segundo SPEN CER e MEADE (1967), tem aproximadamente 30 anos e grande par 
te da literatura existente a respeito do pH ótimo, principalmente aquela que trata da clarificação a níveis de pH re lativamente altos, não é de maior interesse ajém do ponto de vista histórico.

HONIG (1969) publicou que não seria possível uma regra sobre o que padronizaria o pH ótimo, jā que as quantidades dos diferentes tipos de não-açücares que constí tuem o caldo variam de forma considerável. PAYNE (1969), em extenso estudo sobre as reaçōes do processn de clarificação, afirmou que os esforços para se chegar a um procedimento que seja aplicável a todos os caldos extraídos, têm trazido à literatura especializada, informações de modificações de to das as espécies. Afortunadamente, a simples aplicação de cal até se alcançar um pH entre 7,5 e 8,5 produzirá normalmente e com caldo fresco, uma clarificação satisfatória.

Para SPENCER e MEADE (1967), o pH ótimo a que se deve levar o caldo mediante alcalinização, depende de mui tas condições e varia segundo a situação da fábrica, a vari edade e o grau de maturidade da cana, a capacidade do equipamento de decantação e outras condições locais. HONIG (1969) descreve que, com base no conhecimento das reações fundamen tais que têm lugar na clarificação, é compreensível que se estabeleça uma limitação prática dos valores de $\mathrm{pH}$ que venham a ser aplicados. Se é demasiadamente baixo o pH do cal do clarificado, então não se conseguirá de modo completo a 
precipitação de fosfatos, sesquióxidos e ácido silícico. Uma alta alcalinidade tem como vantagem uma completa precipi tação dos não-açúcares inorgânicos removíveis, e como desvantagem a decomposição de açúcares redutores.

Quanto ao efeito do aquecinento, demonstrou-se que é um importante contribuinte, principalmente na for mação de precipitados compostos de não-açücares nitrogenados, lipídeos, sesquióxidos e ácidos silícicos.

BAIKOW (1967) faz considerações alusivas ao efeito da temperatura. Este autor relata que o caldo bruto caleado que entra no clarificador deve ser aquecido à tempe ratura em torno de $104{ }^{\circ} \mathrm{C}$, ligeiramente acima do ponto de ebulição do caldo de cana com $13-16^{\circ}$ brix. A esta temperatura a viscosidade do caldo é diminuída. Em temperaturas abaixo desta faixa, a clarificação passa a apresentar maiores difí culdades devido a lentidão do assentamento do material em suspensão no caldo. A temperatura elevada é importante deví do a necessidade de coagulação de albuminas, substâncias ni trogenadas e floculação de fosfatos no caldo.

\subsection{Caldo de Cana}

0 caldo de cana, conforme a descrição de DEL GADO (1969), seria um líquido opaco, de cor parda ao verde 
escuro, espumoso, viscoso e de reação äcida, cuja composição varia dentro de largos limites, com a variedade, idade e sanidade da cana, clima, solos, tratos culturais e com as condições que presidem a sua extração pelas moendas. De maneira geral, encerra em solução todos os constituintes solú veis existentes na cana, como sacarose, açücares redutores, sais orgânicos e irorgânicos, ảcjdos orgânicos, matérias ni trogenadas como proteínas, aminoácidos, pentosanas e pectinas. E em suspensão, os insolüveis leves e pesados, como ba gacilho, fibra, matêrias corantes, cera e areia.

A maioria dos trabalhos que publicam os componentes do caldo de cana mostra praticamente a mesma faixa de quantificação para as mesmas familias de componentes con siderados.

A seguir, é apresentado um quadro demonstrativo da composição do caldo proposto por SPENCER e MEADE (1967) . 
Componen te.

- Açūcares

Sacarose

Glucose

Frutose

- Sais

De ācidos inorgânicos

De àcidos orgânicos

- Acidos Orgânicos Livres

Acidos carboxílicos

Aminoācidos

- Outros Não-Açúcares Orgânicos

Proteínas

Gomas

Ceras

- Mão Identificados
\% de Sōlidos Solúveis

$75-92$

78-88

2-4

$2-4$

$3,0-7,5$

$1,5-4,5$

$1,0-3,0$

$0,5-2,5$

$0,1-0,5$

$0,5-2,0$

$0,50-0,60$

$0,30-0,60$

$0,05-0,15$

$3,0-5,0$

Sob outro aspecto, o caldo de cana seria um dispersóide constituído de componentes com vários níveis de dispersão. Em adendo a -sto, mostra-se, a seguir, uma tabela sugerida poi Weimarı e Ostwald, citados por PAYNE(1969). 


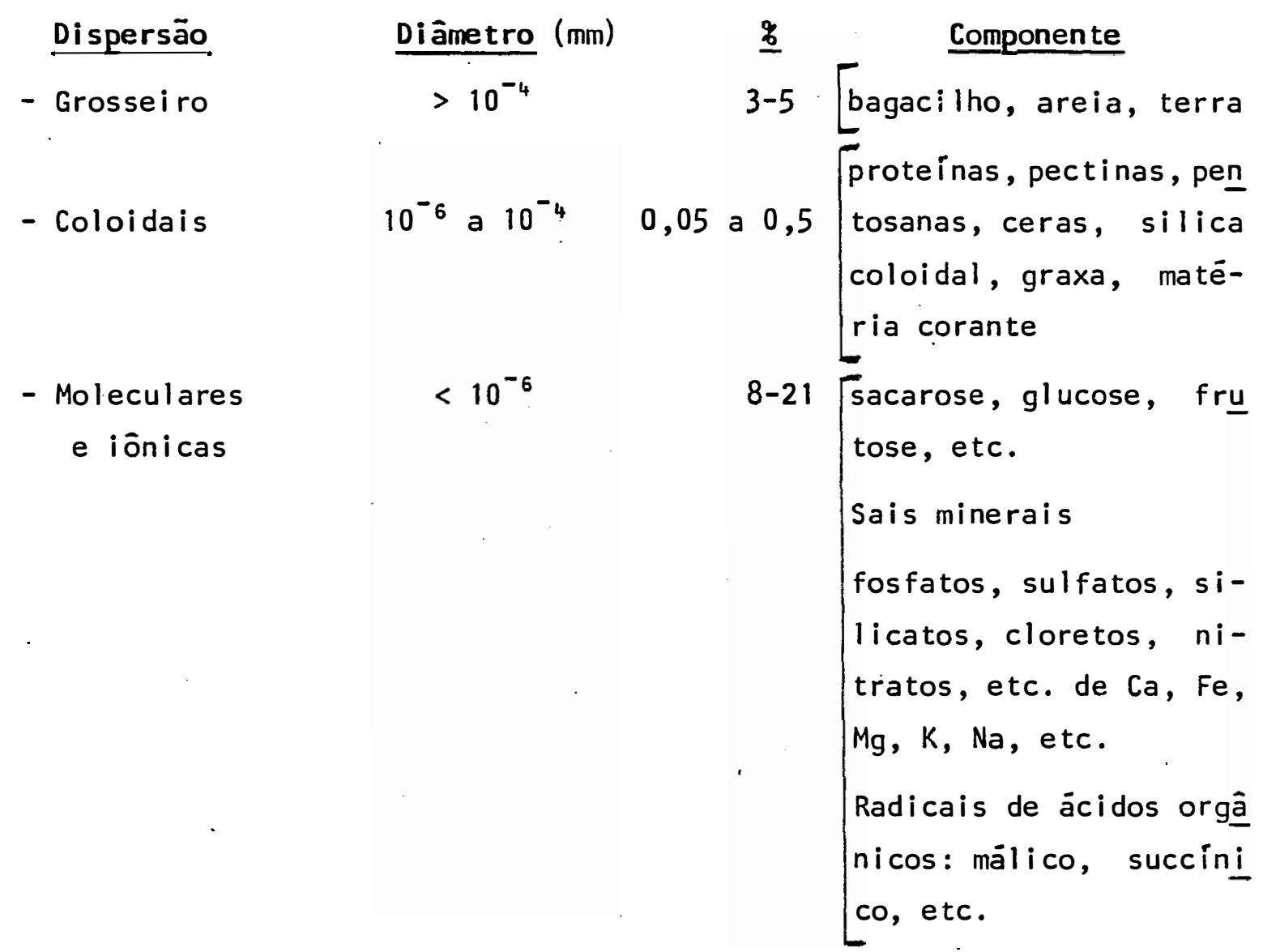

BENNETT (1957) conceitua o caldo de cana co mo um fluido biológico complexo, com partículas em suspensão na ordem de $2,5 \times 10^{8}$ a $1,2 \times 10^{9}$ partículas/m1, onde 85\% teriam diâmetro na faixa de $2 \mu$ e $5 \%$ na faixa de $4 \mu$, ain da apresentando tamanhos máximos $n$ s ordem de $6 \mu$ de diâmetro. Este autor classifica os tipos de partículas como cerosas, polissacarídeos e suspensões minerais.

Sem sombra de dúvida, todas as técnicas e tratamentos efetuados no caldo de cana em processo, têm os 
seus rendimentos dependentes de vârios fatores, principalmente das características que o próprio apresenta. Muitas são as determinantes que ditam estas características. A co meçar pela variedade, que traz via matrizes genéticas, todo um complexo universo de caracterizações e diferenciaçōes. E através dos geneticistas, esta ou aquela variedade é mais difundida dependendo do contexto, circunstância e necessida de da região.

STUPIELLO (1986) mostra muito bem fatos de $\underline{s}$ ta natureza ao exemplificar o Brasil na década sctenta, quan do se definia ou se optava por uma variedade em função da produtividade agrícola. Esta postura foi mudada já no fim da mesma década com o surgimento do Programa Nacional do A 1 cool e, majs tarde, com o pagamento de cana pelo teor de sa carose. Por outro lado, existe a importância da correspondência da matéria prima sob uma ótica agroindustrial, onde ela deve apresentar resistência a pragas, produtividade em vărios tipos de solos, resistência a moléstias, teor de sacarose, teor de fibra, etc...

MULLINS e ROACH (1986) postulam que as varie dades modernas são complexos híbridos originár os da hibridização de canas nobres com outras sem esta característica. Entretanto, o autor confirma que a exata contribuição de cada espécie de cromossomas ao final da interação não é exa tamente conhecida. Esta tese fica bem patenteada quando ana 
lisamos o estudo de MUJICA et alii (1978) que fez uma pesquisa comparativa de 22 variedades em Cuba, obtendo diferen ças significativas entre elas, principalmente nos ítens cres cimento, maturação e tonelada métrica de açúcar/ha.

Com o mesmo propóstio, SHARMA, JOHARY e RAO (1979) estudaram o comportamento de diferentes variedades na India, sob condições uniformes de clarificação e, neste aspecto, encontraram diferenças significativas no comporta mento das mesinas.

Outra determinante importante na característica do caldo é sua flora microbiana. HERNANDEZ, DAUVAL e PE REZ (1978) afirmam serem Bacillus, Leuconostoc, E. coli e aerógenes os microrganismos predominantes no caldo e a ação que eles aí exercem dependerā de suas características metabólicas. Podem ocorrer fenômenos provocados pelos microrga nismos gerando a formação de caracteres indesejāveis no cal do, tais como polimerização de radicais glucose e formação de dextrana. Carruthers, citado por esses autores, evidencia este tipo de manifestações através do desbalanceamento do "pool" de ácidos do caldo. Também pode ser determinante na característica do caldo o fato da cana ter sido ou não q $\cdot$ a $\underline{i}$ mada antes do processamento. DELGADO (1978) fez amplo estu do sobre o assunto e conjuga estas condições com a eficiência e rapidez do binômio operacional corte/processamento a nível de poder vir ou não a influir na característica do 
caldo.

Outro ítem a ser considerado é o teor de ma térias estranhas, tais como raízes, terras, pedras, metais, etc. CHINLOY (1972) considera que as circunstâncias operacionais que podem vir dificultar o trabalho do homem no cam po, tais como áreas onde não pode haver queima, áreas sujei tas a inundação, condiçōes climáticas e qualificação do pró prio trabalhador, são tambêm responsáveis pela presença de matérias estranhas no caldo em processamento.

GIL et alii (1986), estudando o assunto deta lhadamente, concluiram que o tipo de solo não seria um fator tão influente na composição das matérias estranhas, pó rêm a forma de recepção da matêria-prima seria um ítem de significativa influência.

Inúmeros parâmetros, alêm dos abordados, são decisivos na formação do perfil do caldo de cana. Pode-se também citar os índices pluviométricos da região, tipo de solo, qualidade da água de irrigação, situação climática da região, utilização ou não de maquinário agrícola, etc.

Portanto, esse produto biológico apresenta $\underline{u}$ ma certa facilidade em ser influenciado na sua composição qualitativa e quantitativa por uma imensa série de fatores.

E importante que esta idéia fique bem conso lidada e explícita, porque o objetivo principal do trabalho, que é a avaliação da eficiência de alguns polieletrólitos usa 
dos na clarificação, fica tambêm, de certa forma, condicio nado à situação química do caldo, que pode variar de região para região ou até de uma fábrica para outra dentro da mesma região.

Tudo is to deixa uma base para se acreditar na variação dos constituintes do caldo. Estes compostos, al guns de maneira mais acentuada do que outros, podem gerar problemas indesejâveis na fäbrica e, portanto, deve ser fe to o máximo de esforço para eliminá-los do processo.

\subsubsection{ALGUNS COMPONENTES DO CALDO E SUAS IMPLICA- ÇÕES A NÍVEL DE PROCESSAMENTO}

\subsubsection{Açúcares redutores}

Segundo CARDENAS (1977), os açúcares reduto res são facilmente transformados em temperaturas em torno de $100^{\circ} \mathrm{C} \mathrm{e} \mathrm{pH} 8$, com a consequente formação de ácidos orgânicos escuros e coloridos. São reativos e podem combinar com aminoácidos, gerando produtos coloridos (Reação de Mail 1ard). 


\subsubsection{Sais de ācidos orgânicos não nitro- genados}

MARTIN (1969) afirma que estes produtos for mam compostos melassigênicos, o que contribui para o aunento de viscosidade. Por outro 1ado, também se tornam fatores de incremento na formação de incrustações.

\subsubsection{Não-açúcares nitrogenados}

Seriam principalmente aminoäcidos e proteinas. Contribuiriam para um aumento da viscosidade, tornando problemática a cristalização da sacarose. Também devido ao fato de que os aminoácidos são oticamente ativos, poderia se pensar que serian capazes de afetar a análise polarimétrica dos açücares nos produtos da fábrica.

\subsubsection{Ceras e 1ipídeos}

Os lipídeos e ceras que escapam à separação na clarificação do caldo, conforme BALCH (1969), manifestam interferências nas operações de fabricação subsequentes, co mo por exemplo, retardo na etapa de filtração. 


\section{$2 \cdot 3 \cdot 1 \cdot 5$. Gomas}

A presença significativa de substâncias gene ricamente denominadas por gomas é decorrente de uma clarifi cação não bem conduzida; contribui para o aumento da viscosidade do xarope e das massas cozidas, perturbando os estâa gios de cristalização e centrifugação.

\subsubsection{Não-açúcares inorgânicos}

Conforme afirmativas de HONIG (1969), una das principais metas da purificação ê a separação de uma máxima quantidade de não-açúcares inorgânicos, que são considerados de natureza insolûvel ou que se tornam insolúveis duran te a operação de concentração e cristalização, contaminando o açúcar elaborado.

Em particular, a separação do ácido silícico, sesquióxidos, fosfatos e algumas vezes dos sulfatos, ê essencial para a correta elaboração do açúcar cru de alto grau. Do ponto de vista do trabalho de refinação, todos os não- $\underline{\mathrm{a}}$ çû́cares inorgânicos podem ser classificados como nocivos.

\section{$2 \cdot 3 \cdot 1.7$. Ferro}

PAYNE (1969) considera que o teor de ferro no caldo pode advìr do somatório de uma concentração origi- 
nalmente existente e mais um teor adquirido durante a sua extração pelas moendas.

Segundo BROWNE e ZERBAN (1941), a presença do ferro na fabricação do açúcar revela um notável efeito na coloração do caldo, destacando-se, principalmente, as suas reaçōes com substâncias polifenólicas.

\subsection{Polieletrólitos}

\subsubsection{CARACTERÍSTICAS geRAIS DOS POLIELETRÓLITOS}

Os polieletrólitos podem ser definidos como copolímeros de acrilamida e acrilato de sódio com longas ca deias e alto peso molecular. São também conhecidos como poliacrilamidas parcialmente hidrolisados. Esses polímeros $1 \underline{i}$ neares seriam então essencialmente caracterizados por dois tipos de ligação monômera, a ligação ácido acrílico e a lí gação acrilamida. As unidades ácido acrílico, nas quais es tãó geralmænte presentes sal de sódio, proporcionam sítios ativos para se ligarem com partículas de impurezas, enquanto as unidades acrilamidas proporcionam o suporte principal da cadeia polimérica. Em termos espaciais, BENNETT (1975) considera que, de modo geral, as estruturas moleculares de $\underline{s}$ ses polímeros sintéticos apresentam em média uma distribui 
ção dos radicais do ácido acrílico na razão de um sítio atí vo para cada vinte unidades de monômeros. Isto ratifica uma posição da teoria onde se sabe que a distribui.ção espacial dos sítios ativos deve, no caso de compostos desta nature za, se posicionar na estrutura facilitando os balanços do $\underline{\mathrm{e}}$ feito estérico e de repulsã்o eletrostática intramolecular. 0 mercado de polieletrólitos, de uma maneira global, apresenta produtos do tipo aniônico e catiônico, fi. cando a critério de cada linha de produção eleger aquele que the será mais conveniente. O tipo aniônico, mais comumente usado nas usinas de açúcar, pode ser caracterizado através do mode1o

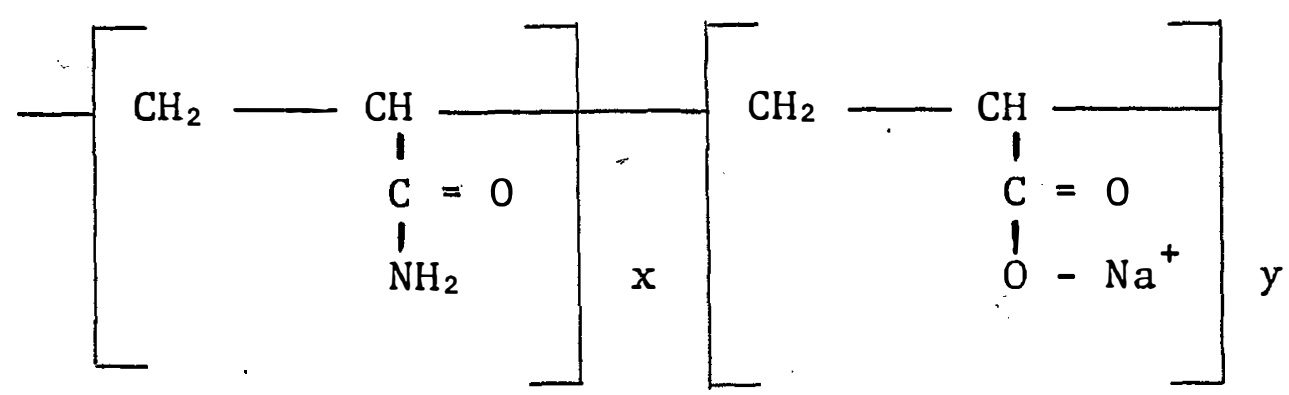

enquanto o catiônico pode ser representado na forma:

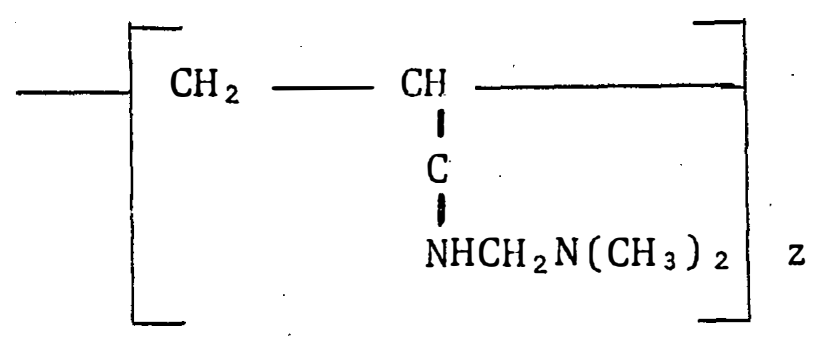


Quanto ao peso mole'cular, que é um ítem importante por estar ligado ao comprimento da molécula, WHAYMAN e CRESS (1974), DOW CHEMICAL COMPANY (1975) e CHEN et alii (1983) confirmam ser da ordem de milhões, variando ge ralmente de 1 até 10 .

Esses compostos solúveis em âgua, que podem se apresentar tanto na forma sólida quanto na forma líquida ou em emulsão, geram soluçōes incolores de considerável vís cosidade. VAN OLPHEN (1963) afirma que a alta viscosidade da solução de polieletrólito é um fenômeno da presença de molế culas distendidas. O efeito da carga elétrica, responsável também pela distensão das moléculas, é referido como um $\underline{e}$ feito de eletroviscosidade.

0 arranjo molecular destes polímeros estabelece uma grandeza muito importante conhecida como grau de hidrôlise, que segundo SILVA Jr. e SILVA (1976), além de proporcionar a distribuição de cargas negativas é responsável pela ligação das partículas floculadas com a molécula, criando um flóculo maior, de rāpida sedimentação. o grau de hidrólise seria a percentagem de grupos acrilatos presentes na sua molécula. Considerando o modelo estrutural

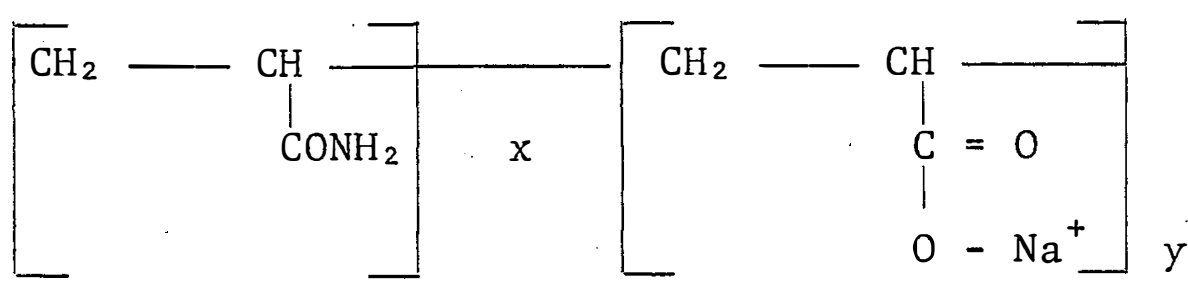


essa grandeza é assim expressa:

Grau de Hidrólise $=\frac{100 y}{[x+y]} \stackrel{\circ}{\circ}$

Quanto à aplicação, a literatura e os fabri cantes, de uma maneira geral, recomendam que sejam utilizados através de soluçōes aquosas bem diluídas na faixa de $0,05 \%$ a $0,10 \%$ e no caso para tratamento do caldo de cana, dosagens que devem variar na faixa de 1 a 5 ppm, condicionando, entretanto, para este último caso, que a fábrica de ve realizar testes preliminares para eleger qual a concentração mais adequada para suas condições operacionais.

0 aparecimento desses produtos no setor açu careiro foi a partir do início da década de cinquenta, sendo o período de 1959 a 1963, segundo CHEN (1974), marcante na sua evolução com o aparecimento de novos polímeros no mercado, principalmente alguns de fabricação alemã. As us $\underline{i}$ nas do Havaí foram, na fase inicial de uso, grandes difuso ras desta técnica.

\subsubsection{MECANISMO DE FUNCIONAMENTO DOS POLIELETRÓLITOS}

A primeira circunstância que se deve analisar no funcionamento do polieletrólito é o universo onde $\underline{e}$ le atuará, ou seja, o caldo de cana. Neste contexto, ele de 
verá estar frente a vários tipos de substâncias, inclusive as de aspecto gelatinoso e que não se cristalizam, podendo se apresentar no estado físico coloidal. Segundo BOTELHO (1951), essas soluçōes coloidais apresentam uma rápida mob $\underline{i}$ lidade vibratória de suas partículas e que, desde muito tem po, se conhece como movimento browniano, que nada mais é do que uma ampliação do movimento molecular; apresentam determinado potencial constituído pela energia, de certa forma prisionada, e que fora aplicada para a dirisão da substância em partículas de pequeníssimas dimensōes, a fim de au mentar-1he a superfície. Assim, a carga elétrica dessas par tículas e a energia superficial se comportam como forças aı tagônicas; a primeira, de sinal igual entre as partículas, atua no sentido da dispersão, por sua repulsão eletrostátí ca; e a outra obriga as partículas a se agregarem no sentido da redução da superfície.

Por outro lado, todo o envolvimento de íons no sistema, em vista de suas cargas elétricas, influenciam no estado coloidal e, portanto, influenciarão na floculação destes colóides.

MARON e PRUTTON (1965) também atribuem gran de parte do comportamento das particulas desta natureza a suas atividades eletrocinéticas e a todos os efeitos que po dem influenciā-las. Então, em verdade, os polieletrólitos estão frente a um complexo sistema de cargas que utilizam o 
seu potencial eletrocinético, buscando em movimentação cons tante atingir o seu ponto de equilíbrio.

Por outro lado, CHEN (1977) e JOHARY

afirmam que a função de um bom floculante é aumentar a taxa de decantação de sólidos insolúveis, diminuir o volume de borra e produzir uma boa clarificação no caldo. E evidente que aí uma coisa dependerá da outra e todas dependerão das interações do polieletrólito com as partículas em solução, fenômeno que é promovido pelo efeito das cargas elétricas. CHEN, RAUH e ARELLANO (1983) consideram ainda que o peso mo lecular e o grau de hidrólise são fatores que também contrí buiriall para uma boa performance desses polímeros sintétí cos, o que de certa furma recairá sobre os fundamentos dita dos pelos sistemas de cargas elétricas. 0 mesmo raciocínio é vảlido quando WHAYMAN e CRESS (1974) afirmam que a incl $\underline{u}$ são de grupos iônicos ao longo da estrutura molecular do polímero serve apenas para proporcionar repulsão eletrostát ca, criando, desta forma, uma melhor distensão molecular, fa cilitando a ocorrência da ligação. Ainda WHAYMAN e CRESS (1974) demonstram a relação de dependência da taxa de decan tação em função dos parâmetros grau de hidrólise, potencial zeta e peso molecular, conforme indicam as figuras á seguir. 


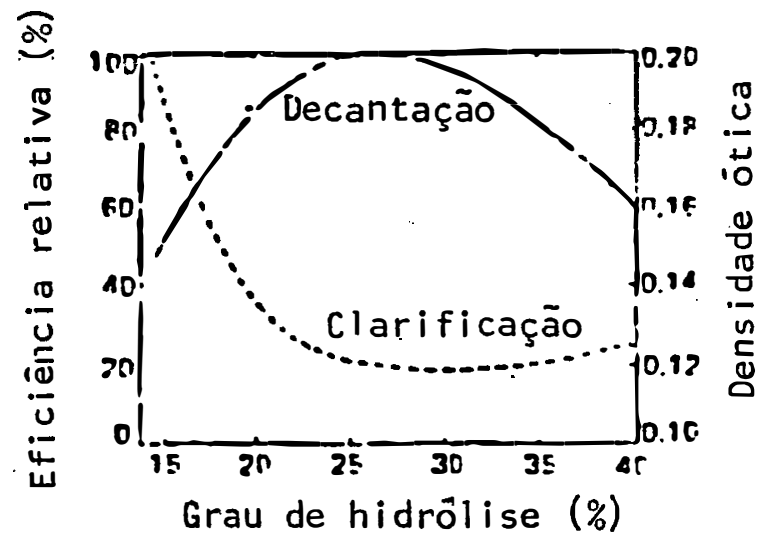

Figura 1 - Efeito do grau de hidrōlise na taxa de decantação e na clari ficação (WHAYMAN e CRESS, 1974).

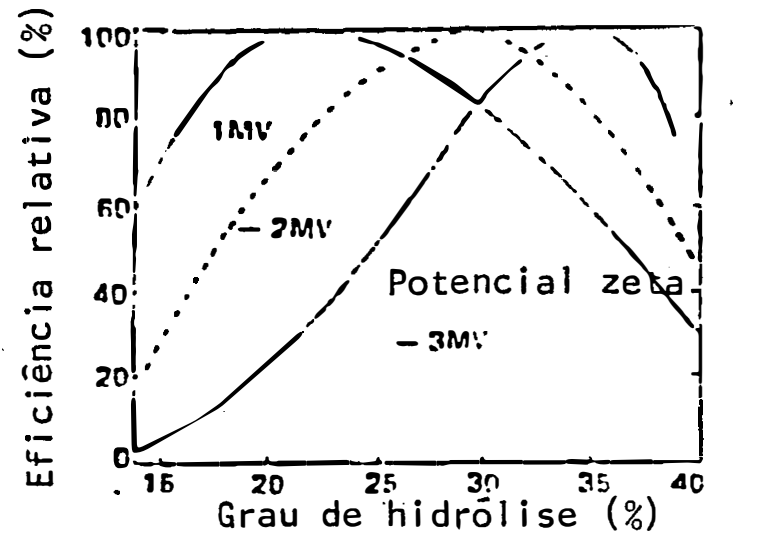

Figura 2 - Efeito do grau de hidrólise e do potencial zeta na taxa de decantação (WHAYMAN e CRESS, 1974).

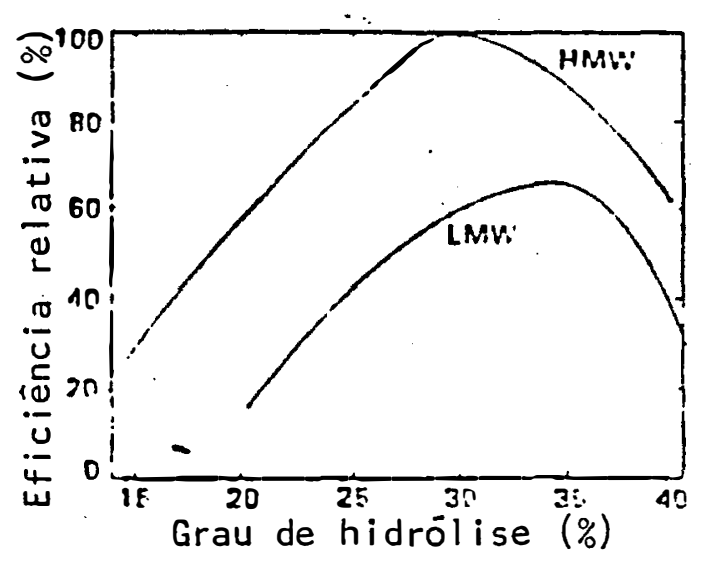

Figura 3 - Efeito do peso molecular e do grau de hidrölise na taxa de decantação (WHAYMAN e CRESS, 1974). 
o fenômeno da floculação exercido por polie letrôlitos seria o fenômeno de agregar partículas, ligando-as em torno da cadeia polimérica, formando pontes de liga ção.

Ruehrwein e Ward, citados por WIIAYMAN e CRESS (1974), foram, segundo estes autores, os primeiros a sugeri rem uma teoria para a floculação. Eles postulam que os polí meros atacam a superfície das partículas em suspensão em um ou mais șítios de adsorção e que parte da cadeia do polímero se estende para dentro do seio da solução. Quando estas extensões da cadeia contatam sítios de adsorção vagos em ou tras partículas, a ponte de ligação é formada. $\Lambda$ s partículas são deste modo compelidas para dentro de pequenos flocos os quais podem crescer para um tamanho limitado em funçãoda quantidade inicial de polímero adsorvido na superfície das partículas.

BERGER (1976) teoriza um modelo para flocula ção, partindo da condição em que as partículas teriam a ten dência natural de serem regidas por dois tipos de força. Uma seria imposta pelas forças atrativas de Van der Walls e a outra seria um produto das forças de interações repulsivas entre cargas eletricamente similares das camadas em tor no das partículas. O autor considera duas partículas de raio a separadas de centro a centro por uma distância $\underline{R}$, confor me mostra a figura a seguir. 


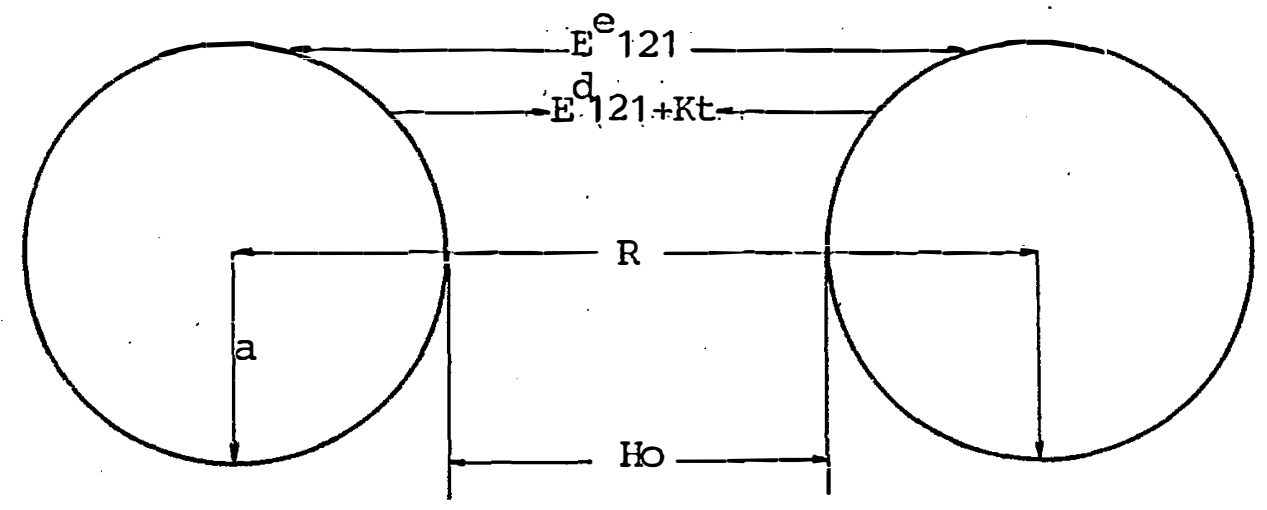

Figura 4 - Força de atração e repulsão (BERGER, 1976).

A interação da distância destes centros seria R-2a, o que o autor chamou de llo. Estas partículas se riam possuidoras de uma certa energia cinética KT igual a $4 \times 10^{-14}$ ergs, à temperatura ambiente.

$\mathrm{Na}$ sequência, para impedir as partículas de concretizar uma adesão, a energia cinética deve exceder as forças de atração de Van der Walls. Este tipo de força é uma função da distância de separação das partículas, seus raios e wa constante fundamental que seria um fator matemá tico de agrupamento conhecido como a constante de Hamaker. Esta interrelação pode ser assim equacionada:

$$
E_{121}^{d}=\frac{-a A_{121} F}{12 \mathrm{Ho}}, \quad \text { onde }
$$


$E_{121}^{d}=$ força de atração entre 2 partículas;

a = raio;

Ho = interação da distância;

$A_{121}=$ constante de Hamaker

$\mathrm{F} \quad$ = fator de correção do dipolo induzido, dependendo da distância de separação.

Se esse modelo matemático é igual a energia cinética Kt das partículas de raio conhecido, conclui-se que a distância mínima de separação para prevenir a floculação deve ser calculada pela equação

$$
\frac{\mathrm{aA}_{121} \mathrm{~F}}{12 \mathrm{Ho}}=4 \times 10^{-14} \therefore \mathrm{Ho}=\frac{\mathrm{aA}_{121}}{4,8 \times 10^{-13}} .
$$

Por outro 1ado, em adição às forças atrativas, as partículas normalmente serão possuidoras de uma for ça repulsiva $E_{121}^{e}$, a qual é proporcional ao potencial de su perfície $\psi^{2}$ e ao raio a, conforme mostra a equação a seguir:

$$
E_{121}^{e}=-\frac{a}{2} \varepsilon_{2} \psi^{2} \ln \left[1+e^{-K H O}\right]
$$

onde

$$
\begin{aligned}
\varepsilon_{2} & =\text { constante dielétrica do líquido } \\
K & =\text { constante do efeito de blindagem }
\end{aligned}
$$


Portanto, para a floculação ocorrer, o somatório das forças atrativas deve ser igual ou maior do que o das forças repulsivas.

$$
\mathrm{E}_{121}^{\mathrm{d}}>\mathrm{E}_{121}^{\mathrm{e}}+\mathrm{Kt}
$$

Por outro lado, basicamente existiriam dois tipos de floculação. BENNETT (1975) cita que a floculação primária seria aquela provocada pela atuação de compostos $\underline{i}$ norgânicos, principalmente através do fosfato de cálcio. Su põem-se aí de 10 a $10^{4}$ unidades de partículas por floco, de pendendo do processo de floculação primário empregado. Enquanto que a floculação secundária é regida pela fixação de impurezas nos sítios ativos das cadeias poliméricas e também estes atacam o grupamento de partículas formadas na flo culação primária. As figuras a seguir ilustram o fenômeno.

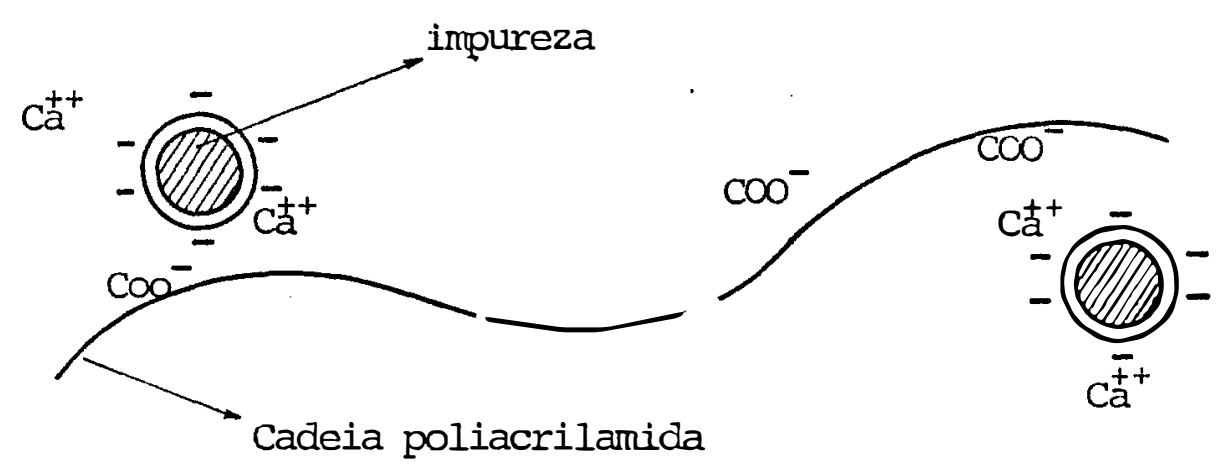

Figura 5 - Diagrama demonstrativo do ataque às partículas impuras pelas unidades da cadeia de poliacrilamida (BENNETT, 1975). 


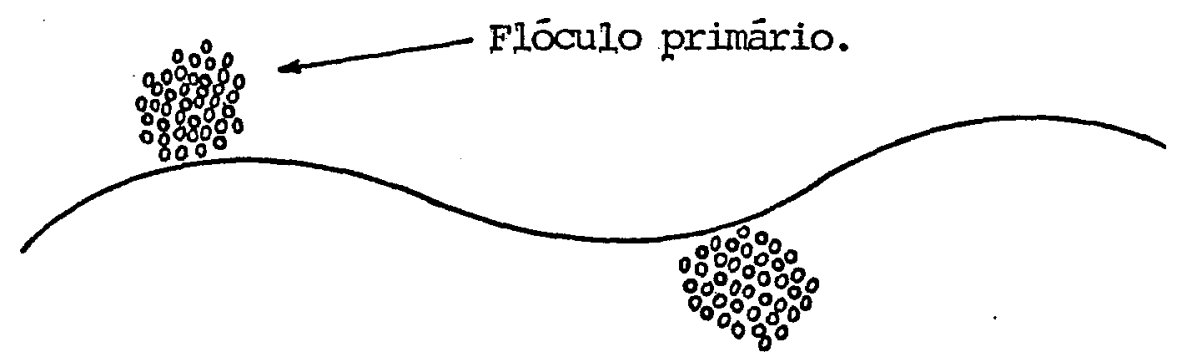

Figura 6 - Floculação secundäria: diagrama para mostrar o ataque de flō culos primärios pela cadeia de poliacrilamida (BENNETT, 1975).

Neste caso, tem-se de $10^{5}$ a $10^{7}$ unidades de partícula por floco, o que iria proporcionar ao floco um ta manho, em alguns casos, com mais de $1 \mathrm{~cm}$ de diâmetro. 0 desenho abaixo mostra esses efeitos.
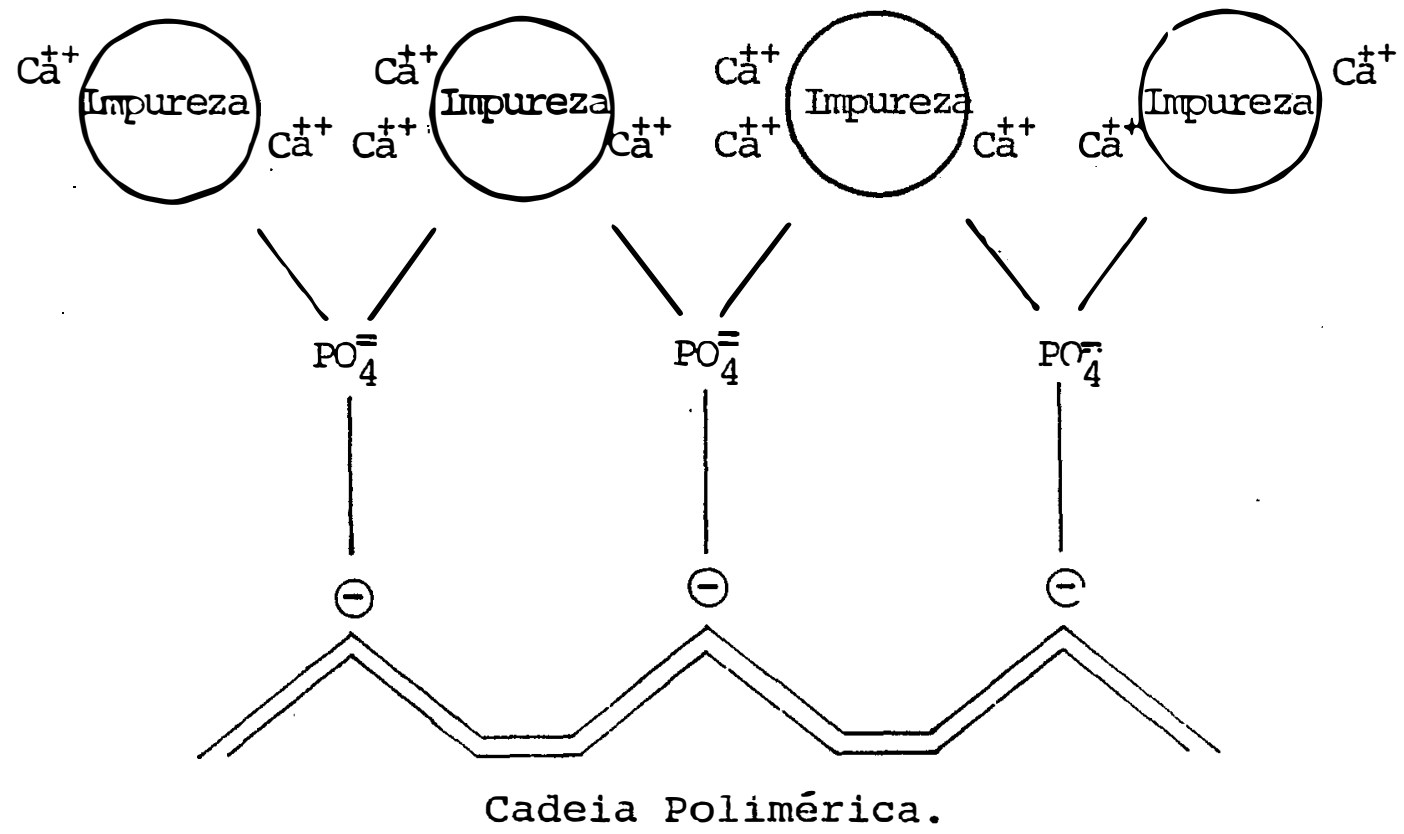

Figura 7 - Efeito da aglutinação das partículas (BENNETT, 1975). 
JOHARY (1982) conceitua a floculação como rẹ sultado da neutralização de carga pela adição de uma substância carregando cargas opostas para que seja suporte das partículas em suspensão.

\subsubsection{APLICAÇÕES INDUSTRIAIS DOS POLIELETRÓLITOS NA CLARIFICAÇÃO DO CALDO DE CANA}

A aplicação de polieletrôlitos pode ser apon tada como a técnica de auxílio à clarificação mais importan te, surgida nas ültimas décadas, principalmente quando a presença de colóides se nota de forma problemática no caldo. Eles incrementam uma marcante evolução na precipitação de certos interferentes não-açūcares, mas não são efetivos com outros.

0 método de adição desses materiais é impor tante. A prática e a experiência têm mostrado que os melho res resultados são obtidos por adiçāo ao caldo caleado após aquecimento.

CHEN e CHEN (1963) citam que a maioria das fábricas seleciona os polímeros seja por trarlição ou for oportunidade, e que a dosagem quase sempre tem sido errônea. Segundo WHAYMAN e CRESS (1974), considerando - consumo na indústria produtora de açúcar bruto a poliacrí lamida parcialmente hidrolisada tem provado ter muito boa 
ceitação. Mesmo assim, existe frequentemente uma necessida de de considerável sensibilidade na scleção de floculantes.

0 reportamento histórico destas aplicações retratam pesquisas jă no início da década de cinquenta, quando LEE (1953) fez estudos com o polieletrólito auxiliar de decantação Krilium. O autor observou e concluiu que quando o produto era adicionado ao caldo de cana, poliânions presu mivelmente adsorviam as partículas coloidais, formando- se pontes entre os grupos reativos e os polímeros. 0 tamanho das partículas formadas muitas vezes atingia seis vezes o tamanho original. O mesmo autor atestou a eficiência do polímero Lytron $\mathrm{X}-886$, que já havia sido testado em laborató rios de usinas da Louisiana, Cuba e Porto Rico, e que depen dendo da qualidade do caldo, trabalhava-se com concentraçōes variáveis na faixa de 1 a $10 \mathrm{ppm}$.

THIBAUT (1954) fez investigações também quan to a aplicação do polímero Lytron X-886 como auxiliar de clarificação durante a caleagem, onde observou uma melhor floculação e um decréscimo na viscosidade do caldo clarificado.

GHASH et alii (1955) também desenvolveram es tudos com o polieletrólito Lytron X-886, a nível de laboratório, trabalhando com volumes de $500 \mathrm{ml}$ de caldo, leite de cal a $15^{\circ}$ Bé e Lytron $X-886$ a $0,1 \%$. Os seus resultados mais satisfatórios foram pronunciados com índice de $\mathrm{pH}$ em torno 
de 7 e a quantificação de polieletrólito em $12 \mathrm{ppm}$.

SLOANE (1956) pesquisou a nível de laborató rio e a nível de fábricas no Havaí, a eficiência dos polie letrólitos Lytron X-886 e Separan 2610. Os resultados leva ram às seguintes conclusões:

- Ambos são suficientemente efetivos e, em alguns casos, $\underline{e}$ conomicamente interessantes. Entretanto, esta efetividade pode variar, dependendo das características do caldo e do tipo de impurezas encontradas no mesmo.

- O Lytron X-886 fornece um poder clarificante melhor do que o Separan 2610 e estabeleceu uma melhor diminuição no volume de lodo.

- Nem o Lytron X-886 e nem o Separan 2610 foram efetivos com caldos de cana da região de Hilo, no Havaí.

MORAN e KELLER (1958), estudando a eficiência do polieletrólito Separan AP-30, concluiram ser o mesmo efí caz nas taxas de decantação, onde provocou aumentos na ordem de $35 \%$, sendo a concentração de 2 ppm a que mostrou me lhor performance, trabalhando-se com soluções a $0,1 \%$.

RAMIREZ (1960) desenvolveu trabalhos exper $\underline{i}$ mentais também com Separan AP-30 na Usina Central Guánica, em Porto Rico. Em primeiro estágio, trabalhou-se com o produto a uma concentração de 0,6 ppm, ajustando-a depois para a ob 
tenção de uma efetividade maior e resultados mais satisfató rios para 2 ppm. As experiências, feitas com uma concentra ção de 5 ppm, mostraram uma grande densidade de lodo obtido, sendo necessário se adicionar água ao sistema para se fazer fluir. Isto reforça a tese de CHEN (1977), que estabe lece particularmente para cada caso a existência de um pon to de concentração ideal. Valores abaixo deles podem gerar resultados aquêm da eficiência esperada e valores acima podem provocar a ocorrência de fenômenos paralelos indese $\underline{j a}$. veis.

Trott e Hutchins, citados por BERGER (1976), tambêm fizeram trabalhos para certificar a resposta do Sepa ran AP-30 na clarificação e trabalhando com solução a $1 \%$ juntamente com a caleagem do caldo obtiveram uma melhora $\underline{e}$ fetiva na clarificação.

Bose e Shrivastava, segundo BERGER (1976), fizeram na India estudos com Lytron e Separan, concluindo que um polímero contendo cátions e ânions deve ser mais efetivo do que um polímero do tipo monofuncional.

CHEN e CHEN (1963) puderam certificar, apös pesquisas com caldos refratários, a significativa contribui ção dos polieletrólitos Separan AP-30 e Krillium, sugerindo as melhores performances na faixa de 0,5 a $1,0 \mathrm{ppm}$.

Osvald e Tluchor, conforme BERGER (1976), tes taram os efeitos floculantes produzidos pelo Separan AP-30 e 
de quatro agentes floculantes fabricados na Checoslováquia. Estes produtos foram o ELP, que seria basicamente um extrato aglutinado de linhaça; Vama I, sal amoniacal de um copo límero vinil acetomaleico; Vama II, tambëm um copolímero ví nil acetomaleico; e o polímero KMA 6634, à base de metacrí lato äcido de sôdio. o eféto du nível de eficâcia desses produtos foi estudado em exploratória a fatores determinan tes como quantidade de floculante adicionado, o sistema de purificação utilizado, a pureza do caldo bruto após tratamento, a estrutura do lodo obtido.

Quando KMA 6634 e o Separan AP-30 foram adicionados à razão de $2 \mathrm{mg} / 100 \mathrm{ml}$, os resultados na sedimenta ção aumentaram em $50 \%$, superando os resultados obtidos pelos outros três floculantes.

Hale e Whayman, citados poir BERGER (1976), estudaram o comportamento dos polímeros Separan AP-30 e Separan AP-273 e Sedipur $\mathrm{TF}_{2}$. Em sulas pesquisas os autores con cluiram que as funções em anâlise dependem de propriedades tais como peso molecular e distribuição de carga. Eles afị mam que os três produtos foram bastante satisfatórios como floculantes, mas suas efetividades variam de acordo com a $\underline{i}$ dade da cana e a técnica de clarificação usada.

Manning e Denny, segundo BERGER $(1976)$, tambëm analisando o Sedipur $\mathrm{TF}_{2}$ e o Separan AP-30, observaram que estes produtos apresentaram uma capacidade de reduzir o 
teor de cinzas no caldo de cana em aproximadamente $0,30 \%$. BERGER (1976) cita que BOSE et alii levanta ram dados analíticos de comportamento com o Separan AP-30 응 perando na faixa de 1 a $3 \mathrm{ppm}$. Os resultados permitiram con cluir que este polieletrólito foi um fator de contribuição para o incremento da capacidade de decantação e de diminui ção para o tempo de aquecimento. Esta ủltima observação nos faz entender a importância que é diminuir o tempo de aquecí mento, não só por um aspecto econômico, mas tambêm porque um aquecimento mais prolongado serve para aumentar a proba bilidade da taxa de decomposição de açúcares redutores, que poderão promover um aumento no índice de cor.

Ainda segundo citação de BERGER (1976), Onna avaliou o rendimento dos polímeros Zuclar 106, Genfloc 156, Separan AP-30, Separan AP-273, Nalcolyte 674, Drewfloc 204, Genfloc 140. Os resultados mostraram boa resposta no aumento da taxa de decantação e na redução da turbidez; alguns destes vieram a provocar a formação de bolhas de gás no cal do clarificado.

CHEN (1977) conseguiu resultados comparativos entre os produtos Sedipur $T_{1}$, Sedipur $\mathrm{TF}_{2}$ e Separan AP30. Os dados permitiram concluir que Sedipur $T_{1}$ mostrou- se superior para clarificação do caldo e também para a taxa de decantação. O autor complementa que a taxa de sedimentação pode não seguir a proporcionalidade correspondente ao aumen 
to da dosagem de polímero, sendo possível de trazer um efe $\underline{i}$ to reverso; e que também is to pode acontecer com algum tipo de caldo, mas não necessariamente com todos os tipos de cal do. Por outro lado, ele mostra ainda que a interação, clari ficação do caldo e taxa de sedimentação, muitas vezes não têm correlação significativa.

SHEPARD (1978), investigando sobre a eficiên cia dos polieletrólitos Superfloc A-110 e Superfloc A-150 e Talosep A-130, pode concluir que entre estes, os floculantes com baixo e médio grau de hidrólise, A-110 e A-130, mos traram melhor rendimento do que aquele com alto grau de hidrölise, A-150. As avaliações foram feitas sobre os parâme tros, percentual do volume final de borra e turbidez no cal do clarificado.

BOSE et alii (1978) testaram em laboratório quatro floculantes fabricados na India. Os produtos testados foram Primafloc A-10, Morarfloc A-40H, Dedenol OT e Hy flock. Os melhores resultados obtidos em termos de volume de lodo decantado, foram conseguidos pelos floculantes Primafloc A-10 e Hyflock, ambos na dosagem de 2 ppm.

RAO e SINHA (1978), em experiências laborato riais com agentes flocr antes no caldo sulfitado, ressaltam os bons resultados de taxa de sedimentação obtidos com o po límero aniônico Califloc A, elegendo 3 ppm como a dosagem $\underline{i}$ deal para se trabalhar com ele. 
JOHARY (1982) desenvolveu um trabalho analisando a eficiência de maneira comparativa dos polímeros Mag nofloc LT-27, Sedipur TF2, Separan AP-30 e Morarfloc, quando em caldo sulfitado. 0 polieletrölito Magnofloc LT-27 a 3 ppm for neceu significativa diminuição no volume de lodo e expressi vo aceleramento na decantação, seguido por ordem decrescente de eficiência dos polieletrólitos Sedipur $\mathrm{TF}_{2}$ a $2 \mathrm{ppm}$, Sepa ran AP-30 a 3 ppm e, finalmente, Morarfloc a 4 ppm. Entretan to, o autor deixa bem clàro que a performance de un floculante pode variar de acordo com o país onde a cana é produzida, bem como a natureza do caldo.

CHEN, RAUH e ARELLANO (1983) desenvolveram tes tes com floculantes em fäbricas na Flôrida, codificando esseśs produtos como A,B e C. Na conclusão do trabalho tecem comentâa rios de cunho teórico, onde ficaram patenteadas importantes observações como serâ visto a seguir.

- 0 aumento da dosagem do produto pode vir a in crementar a sedimentação, mas não é indicação de uma melhora na clarificação.

- 0 aumento da dosagen acima do teor requerido pode provocar decréscimos nos rendimentos.

- 0 polímero pode render bem em determinada fábri ca sob dadas condições, mas pode não trabalhar tão bem em outra fábrica. - A taxa de sedimentação não tem uma correlação direta com o indice de clarificação. 


\section{MATERIAIS E MEETOBOS}

O desenvolvimento da parte prática foi direcionado conforme mostra o modelo a seguir:

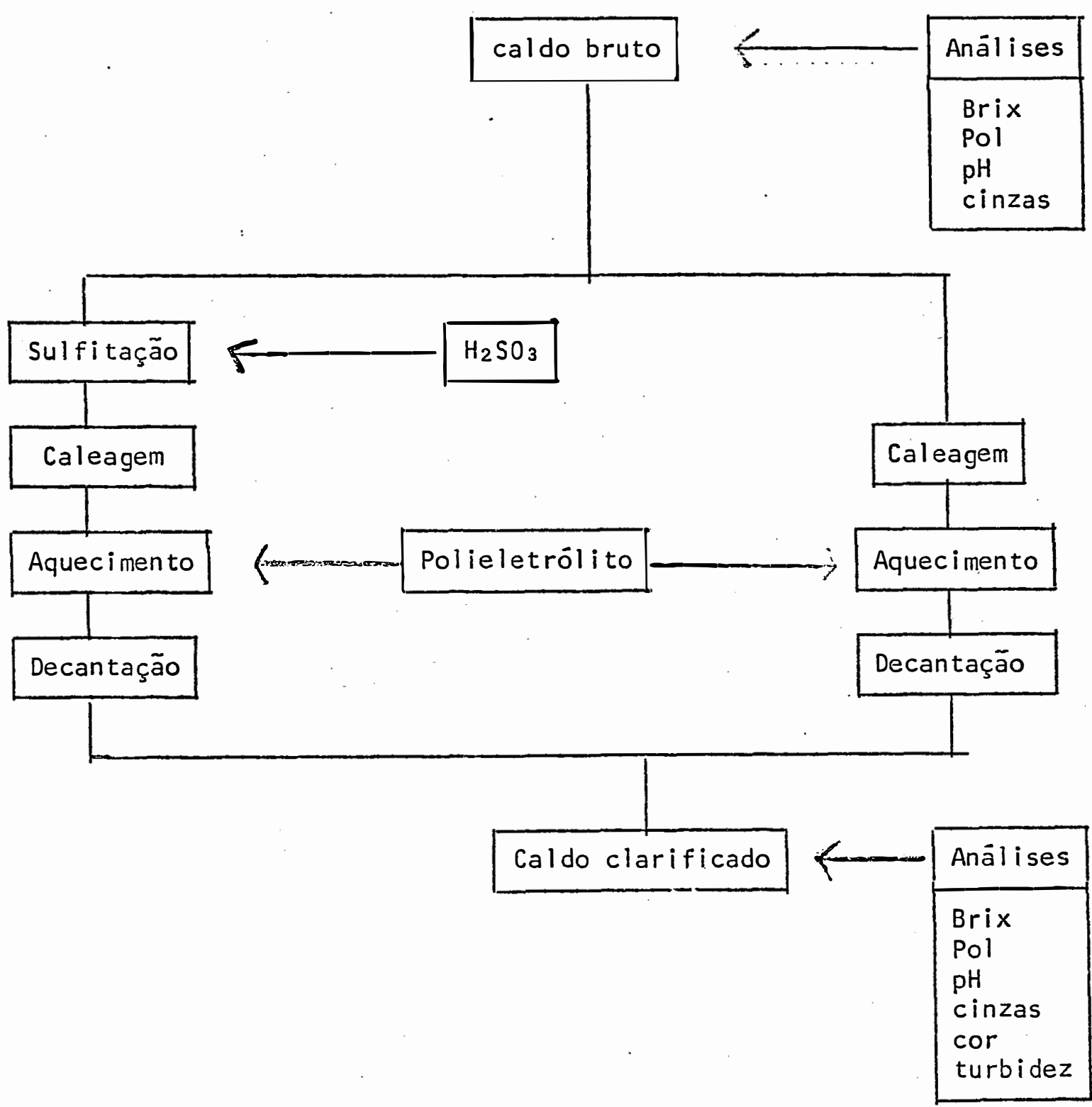




\subsection{Material}

\subsubsection{CALDO DE CANA}

As amostras foram coletadas aleatoriamente na caixa de caldo misto em usina da região de Piracicaba, Estado de São Paulo. O trabalho de laboratório se desenvol veu em fases. Primeiramente trabalhando-se com concentraçōes de polímeros iguais a 1 ppm e ao longo da safra conse cutivamente com concentrações de 2,3 e 4 ppm.

\subsubsection{DECANTADOR DE LABORATÓRIO E PROVETAS}

Conforme descrição de SILVA e SILVA (1976), trata-se de uma cuba de vidro, com um sistema acoplado de hélice para promover a circulação da āgua, resistência elétrica para produzir o aquecimento da mesma e local para en caixe de um termômetro. A parte superior é vedada por placa de metal com vârios orifícios, por onde são colocadas e fi xadas as provetas de $250 \mathrm{ml}$, que receberão o caldo tratado para os ensaios de decantação.

As fotografias a seguir ilustram melhor a descrição do equipamento. 
.50.
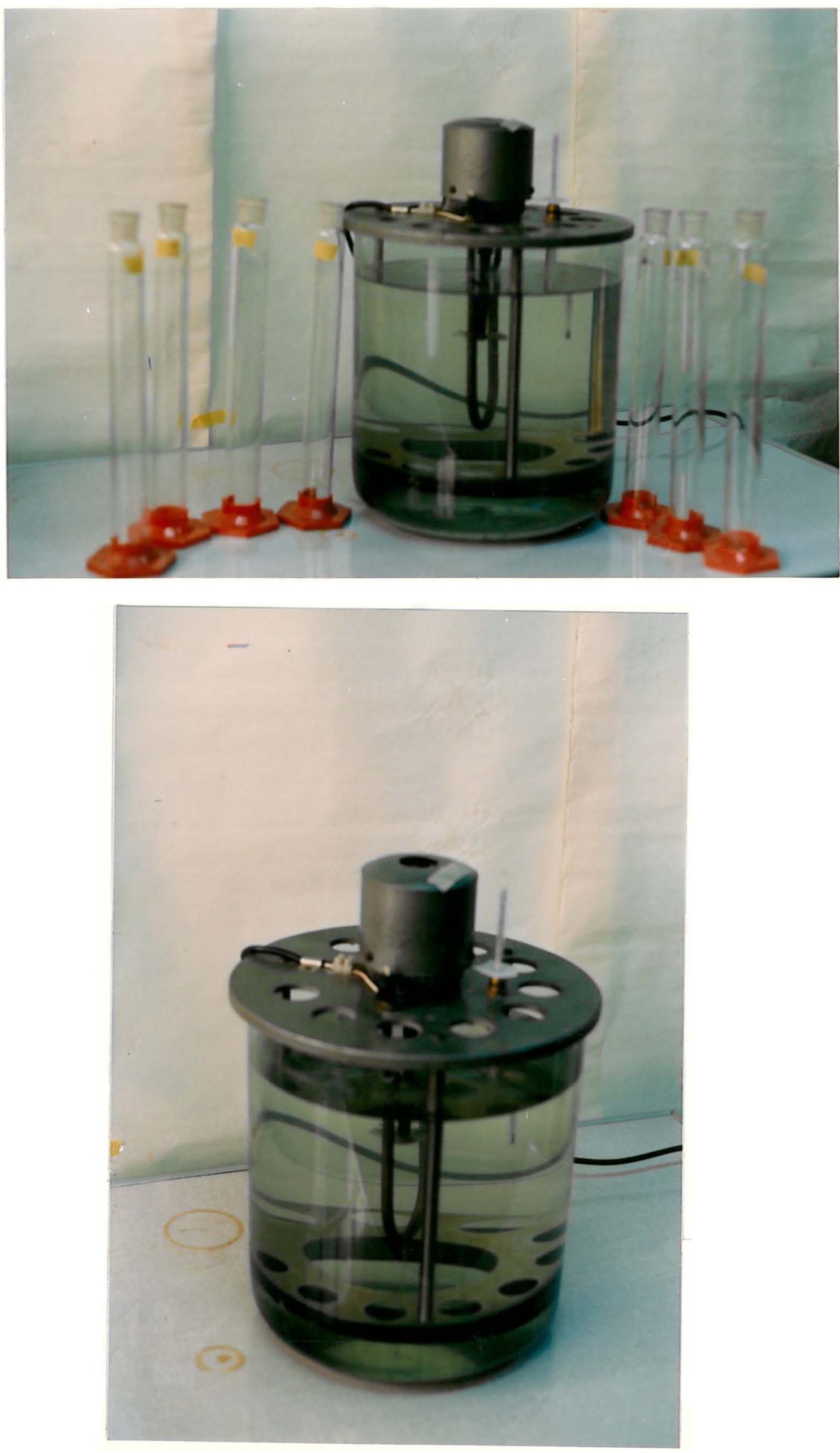
.51 .

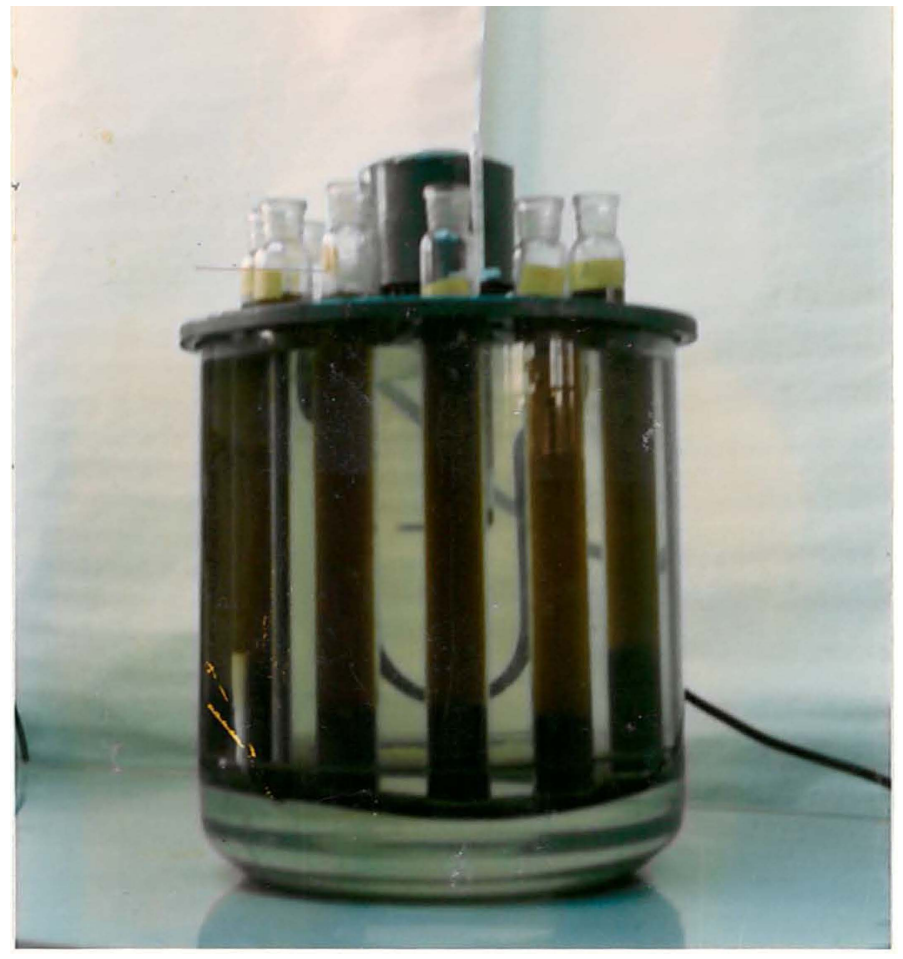




\subsubsection{LEITE DE CAL}

O leite de cal utilizado nos trabalhos foi obtido na mesma unidade produtora onde foi coletado o caldo de cana. A preparação seguiu a técnica descrita por ALMEIDA (1944), onde a suspensão é aferida para a concentração que é normalmente usada na indústria, $94 \mathrm{~g} / 1$ de $\mathrm{CaO}$.

\section{3:1.4, ÁCIDO SULFUROSO}

Foi empregado o ácido sulfuroso produzido por Riede1 Indústrias Químicas.

\subsubsection{POLIELETRÓLITOS}

Foram testados seis polieletrölitos com as seguintes características, segundo os seus respectivos fabricantes : 


\begin{tabular}{|c|c|c|c|c|}
\hline Codificação & $\begin{array}{l}\text { Caracterís- } \\
\text { tica iônica }\end{array}$ & $\begin{array}{l}\text { Ordem de } \\
\text { grandeza do } \\
\text { peso molecular }\end{array}$ & $\begin{array}{l}\text { Concent ração } \\
\text { da sol uçăo } \\
\text { di luída }\end{array}$ & $\begin{array}{l}\text { Estado } \\
\text { físico }\end{array}$ \\
\hline A & Aniônico & $8 \times 10^{6}$ & $0,025 \%$ & emul são \\
\hline B & Aniônico & $8 \times 10^{6}$ & $0,1 \%$ & $\begin{array}{l}\text { sōlido crista } \\
\text { lino finamen- } \\
\text { te dividido }\end{array}$ \\
\hline C & Aniônico & $15 \times 10^{6}$ & $0,1 \%$ & $\begin{array}{l}\text { sölido crista } \\
\text { lino finamen- } \\
\text { de dividido }\end{array}$ \\
\hline D & Aniônico & $5 \times 10^{5}$ & $0,01 \%$ & $\begin{array}{c}\text { líquido xaro- } \\
\text { poso }\end{array}$ \\
\hline$E$ & Aniônico & $4 \times 10^{6}$ & $0,1 \%$ & $\begin{array}{l}\text { sōlido crista } \\
\text { lino finamen- } \\
\text { te dividido }\end{array}$ \\
\hline $\mathrm{F}$ & Aniônico & $6 \times 10^{6}$ & $0,1 \%$ & $\begin{array}{l}\text { sölido crista } \\
\text { lino finamen- } \\
\text { te dividido }\end{array}$ \\
\hline
\end{tabular}

\title{
3.2. MÉtodos
}

\subsubsection{MËTODOS TECNOLŌGICOS}

\author{
a. Sulfitaçāo
}

Utilizaçāo do âcido sulfuroso na proporção recomendada por SPENCER e MEADE (1967), atê pH 4 . 


\title{
b. Caleagem
}

Utilização do leite de cal, neutralizando a té pH 7 conforme preconiza SPENCER e MEADE (1967).

\author{
c. Aquecimento \\ o caldo peneirado teve a sua temperatura ajus
} tada para $35^{\circ} \mathrm{C}$. Depois, devidamente tratado, via caleagem ou sulfocaleagem, foi transferido para um balão de fundo redon do e aquecido em manta até atingir a temperatura de ebulição, aproximadamente $100^{\circ} \mathrm{C}$. O caldo aquecido foi transferi do para as provetas de $250 \mathrm{~m} 1$ da cuba de decantação, onde se desenvolveu o processo de sedimentação das impurezas.

\section{d. Adição de polieletrólitos}

As dosagens seguiram a orientação dos fabri cantes, os quais ratificam o que preconiza, neste aspecto, a literatura de maneira geral. A partir destes produtos foram feitas soluções diluídas e dosadas no caldo de cana na faixa de 1 a 4 ppm.

\subsubsection{MÉTODOS ANALÍTICOS}

\section{a. Brix refratométrico}

Conforme proposto pela Association of Hawaiian Sugar Technologists (1968). 


\section{b. Polarizaçāo}

Pelo método de Schmitz, segundo a Association of Hawaiian Sugar Technologists (1968).

c. $\mathrm{pH}$

Segundo a metodologia publicada pela Associa tion of Hawaiian Sugar Technologists (1968).

\section{d. Cinzas}

Determinadas por condutimetria no rafinômetro Tödt-Golnow, conforme proposto por BROWNE e ZERBAN (1941) .

e. Cor

Metodologia apresentada segundo SPENCER e MEADE (1967) •

f. Turbidez

Conforme a têcnica citada por SPENCER e MEADE (1967) • 


\title{
3.2.3. CÂLCULOS TECNOLŌGIICOS
}

\author{
a. Pureza aparente ao refratômetro \\ Calculada conforme propõem SPENCER e MEADE
}

(1967)

b. Borra: de caldo

Calculada considerando-se o volume de borra e o volume total de caldo, conforme a fórmula seguinte:

$$
\text { Borra: de caldo }=\frac{\text { Volume de borra }}{\text { Volume total de caldo }} \times 100
$$

\subsubsection{MËTODOS ESTATÍSTICOS}

o tratamento dos resultados obtidos deverão entrar nas seguintes matrizes estatísticas:

a. Anālise de variância

Através de blocos inteiramente casualizados, conforme proposto por GOMES (1985). 


\begin{tabular}{c|c}
\hline Causas de Variância (CV) & Graus de Liberdade (GL) \\
\hline Concentração & 3 \\
Polieletrōlito & 6 \\
Concentração x Polieletrōli to & 18 \\
Resíduo & 56 \\
Total & 83 \\
\hline
\end{tabular}

b. Teste de Tukey

Realizado para a comparação das médias, seguindo a indicaçāo de GOMES (1985). 


\section{RESULTADOS}

Apresentamos, a seguir, as médias dos resul tados obtidos em 4 ensaios para cada concentração, grupados dentro de cada parâmetro analítico.

TRATAMENTO $-\mathrm{H}_{2} \mathrm{SO}_{3}+\mathrm{CaO}$

PARAMETRO - Brix

\begin{tabular}{c|c|c|c|c|c}
\hline CONCENTR. & $1 \mathrm{ppm}$ & $2 \mathrm{ppm}$ & $3 \mathrm{ppm}$ & $4 \mathrm{ppm}$ & Média \\
\hline POLIELET. & 13,42 & 14,03 & 13,28 & 14,46 & 13,80 \\
\hline B & 12,87 & 13,83 & 13,10 & 14,41 & 13,55 \\
\hline C & 13,69 & 13,44 & 13,17 & 14,37 & 13,67 \\
\hline D & 13,33 & 13,38 & 13,18 & 14,23 & 13,53 \\
\hline E & 13,37 & 14,02 & 13,11 & 14,27 & 13,69 \\
\hline F & 13,27 & 13,76 & 13,04 & 14,40 & 13,62 \\
\hline T & 13,65 & 13,74 & 13,50 & 14,63 & 13,88 \\
\hline Média & 13,37 & 13,74 & 13,20 & 14,40 & \\
\hline
\end{tabular}


TRATAMENTO $-\mathrm{H}_{2} \mathrm{SO}_{3}+\mathrm{CaO}$

PARAMETRO - POI

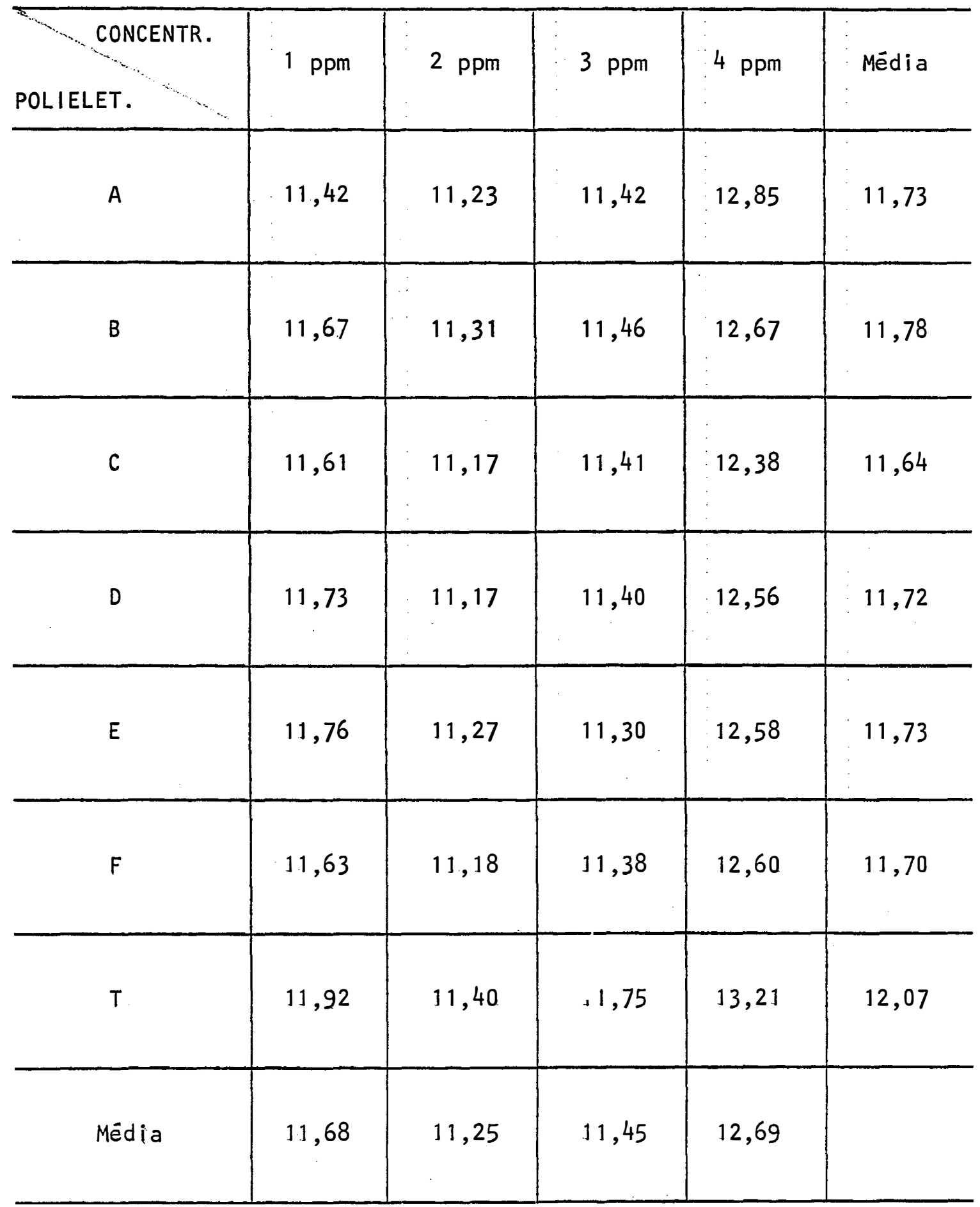


.60

TRATAMENTO $-\mathrm{H}_{2} \mathrm{SO}_{3}+\mathrm{CaO}$

PARAMETRO - Pureza

\begin{tabular}{c|c|c|c|c|c}
\hline CONCENTR. & $1 \mathrm{ppm}$ & $2 \mathrm{ppm}$ & $3 \mathrm{ppm}$ & $4 \mathrm{ppm}$ & Média \\
\hline POLIELET. & 84,93 & 80,32 & 86,02 & 88,63 & 84,97 \\
\hline B & 90,87 & 81,90 & 87,45 & 87,71 & 86,98 \\
\hline C & 87,43 & 83,03 & 86,68 & 85,86 & 85,75 \\
\hline D & 87,90 & 83,44 & 86,44 & 88,03 & 86,45 \\
\hline E & 87,91 & 80,64 & 86,12 & 87,91 & 85,64 \\
\hline F & 87,62 & 81,39 & 87,37 & 87,24 & 85,91 \\
\hline & 87,24 & 83,10 & 87,24 & $90, \therefore 2$ & 86,88 \\
\hline & & 81,97 & 86,73 & 87,93 & \\
\hline & & & & & \\
\hline
\end{tabular}


TRATAMENTO $-\mathrm{H}_{2} \mathrm{SO}_{3}+\mathrm{CaO}$

PARAMETRO - $\mathrm{pH}$

\begin{tabular}{|c|c|c|c|c|c|}
\hline POLIELET. & $1 \mathrm{ppm}$ & $2 \mathrm{ppm}$ & $3 \mathrm{ppm}$ & $4 \mathrm{ppm}$ & Média \\
\hline$A$ & 6,7 & 6,7 & 6,6 & 6,5 & 6,6 \\
\hline B & 6,7 & 6,8 & 6,6 & 6,6 & 6,6 \\
\hline C & 6,6 & 6,9 & 6,6 & 6,6 & 6,7 \\
\hline$D$ & 6,6 & 6,8 & 6,5 & 6,6 & 6,6 \\
\hline$E$ & 6,6 & 6,9 & 6,5 & 6,6 & 6,6 \\
\hline$F$ & 6,6 & 6,8 & 6,4 & 6,6 & 6,6 \\
\hline$T$ & 6,6 & 6,8 & 6,6 & 6,5 & 6,6 \\
\hline Média & 6,6 & 6,8 & 6,5 & 6,6 & \\
\hline
\end{tabular}


.62 .

TRATAMENTO $-\mathrm{H}_{2} \mathrm{SO}_{3}+\mathrm{CaO}$

PARAMETRO - Cinzas Condutimétricas

\begin{tabular}{|c|c|c|c|c|c|}
\hline${ }_{-}$ & $1 \mathrm{ppm}$ & $2 \mathrm{ppm}$ & $3 \mathrm{ppm}$ & $4 \mathrm{ppm}$ & Média \\
\hline A & 0,56 & 0,58 & 0,58 & 0,55 & 0,57 \\
\hline B & 0,55 & 0,58 & 0,57 & 0,53 & 0,56 \\
\hline C & 0,56 & 0,58 & 0,59 & 0,54 & 0,57 \\
\hline$D$ & 0,57 & 0,55 & 0,57 & 0,55 & 0,56 \\
\hline E & 0,56 & 0,59 & 0,58 & 0,54 & 0,57 \\
\hline $\mathrm{F}$ & 0,57 & 0,58 & 0,57 & 0,54 & 0,57 \\
\hline$T$ & 0,58 & 0,61 & 0,60 & 0,56 & 0,59 \\
\hline Mëdia & 0,56 & 0,58 & 0,58 & 0,54 & \\
\hline
\end{tabular}




\begin{tabular}{|c|c|c|c|c|c|}
\hline POLIELET. & 1 ppm & $2 \mathrm{ppm}$ & $3 \mathrm{ppm}$ & $4 \mathrm{ppm}$ & Mēdia \\
\hline$A$ & 12614 & 16539 & 12583 & 11791 & 13382 \\
\hline B & 12515 & 16744 & 12554 & 11685 & 13375 \\
\hline C & 12921 & 13920 & 13431 & 11614 & 12972 \\
\hline$D$ & 14274 & 15701 & 11338 & 11889 & 13300 \\
\hline$E$ & 13703 & 15411 & 12760 & 12411 & 13571 \\
\hline$F$ & 12123 & 16423 & 11795 & 11440 & 12945 \\
\hline$T$ & 14140 & 16642 & 12761 & 12112 & 13914 \\
\hline Mëdia & 13184 & 15911 & 12460 & 11849 & \\
\hline
\end{tabular}


TRATAMENTO $-\mathrm{H}_{2} \mathrm{SO}_{3}+\mathrm{CaO}$

PARAMETRO - Turbidez

$(*)$

\begin{tabular}{|c|c|c|c|c|c|}
\hline CONCE & $1 \mathrm{ppm}$ & $2 \mathrm{ppm}$ & $3 \mathrm{ppm}$ & $4 \mathrm{ppm}$ & Mëdia \\
\hline A & 72 & 90 & 71 & 150 & 96 \\
\hline B & 70 & 74 & 77 & 160 & 95 \\
\hline C & 79 & 96 & 74 & 155 & 101 \\
\hline$D$ & 106 & 91 & 83 & 164 & 111 \\
\hline$E$ & 78 & 77 & 77 & 158 & 97 \\
\hline$F$ & 92 & 78 & 79 & 164 & 103 \\
\hline$T$ & 66 & 82 & 76 & 151 & 94 \\
\hline Média & 81 & 84 & 76 & 157 & \\
\hline
\end{tabular}

(*). Dados transformados em raiz de $x+\theta$ 
.65 .

TRATAMENTO $-\mathrm{H}_{2} \mathrm{SO}_{3}+\mathrm{CaO}$

PARÁMETRO - \% Decantado

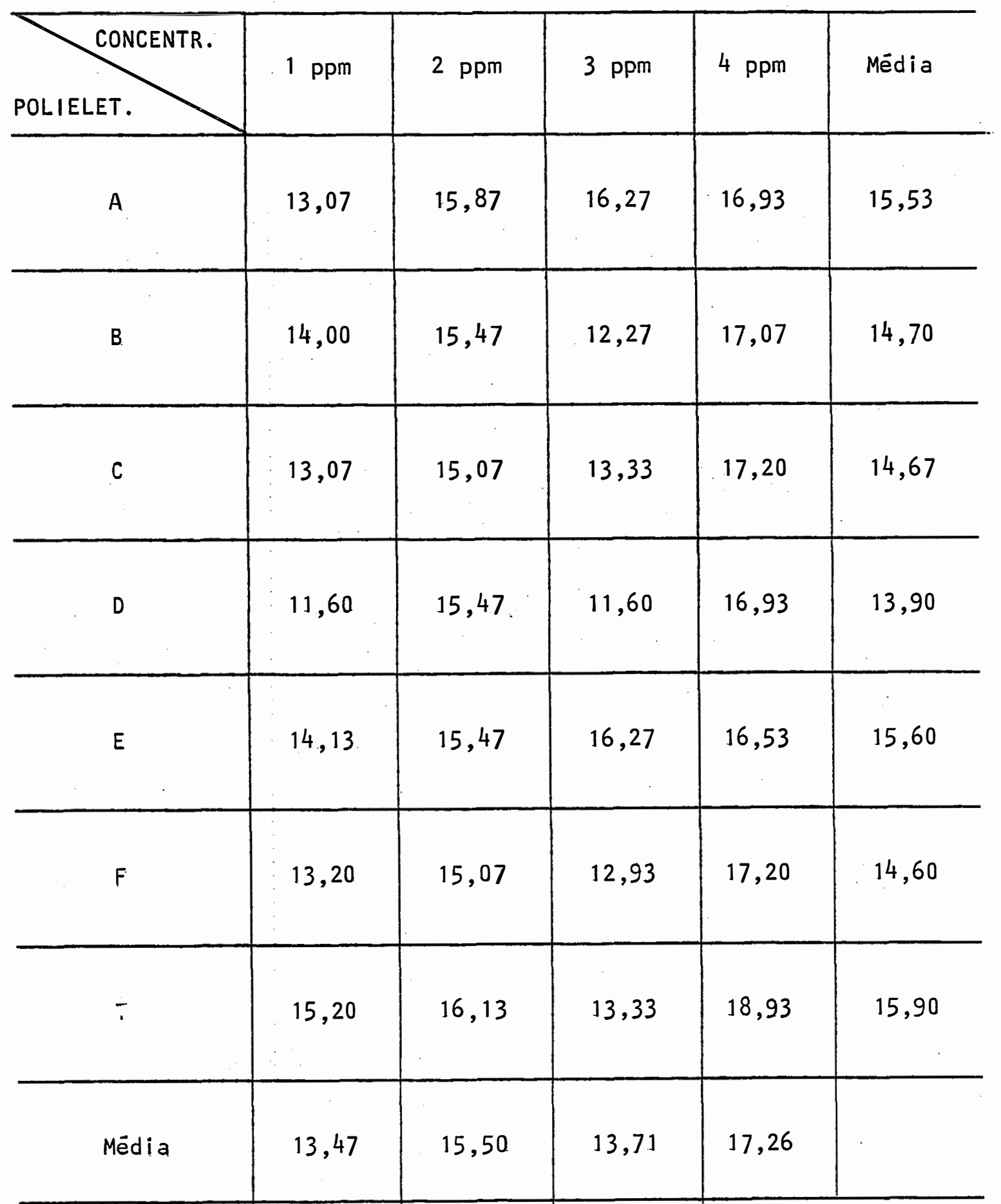




\begin{tabular}{|c|c|c|c|c|c|}
\hline OLIELET. & $1 \mathrm{ppm}$ & $2 \mathrm{ppm}$ & $3 \mathrm{ppm}$ & $4 \mathrm{ppm}$ & Mëdia \\
\hline A & 13,35 & 14,64 & 13,93 & 14,70 & 14,15 \\
\hline B & 13,17 & 14,42 & 13,80 & 14,84 & 14,06 \\
\hline$c$ & 13,35 & 14,48 & 13,78 & 14,53 & 14,04 \\
\hline D & 13,18 & 14,41 & 13,82 & 14,49 & 13,97 \\
\hline$E$ & 13,23 & 14,63 & 13,84 & 14,39 & 14,02 \\
\hline$F$ & 13,14 & 14,48 & 13,88 & 14,58 & 14,02 \\
\hline$T$ & & 14,66 & 14,20 & 14,97 & 14,30 \\
\hline Mêdia & 13,26 & 14,53 & 13,89 & 14,64 & \\
\hline
\end{tabular}




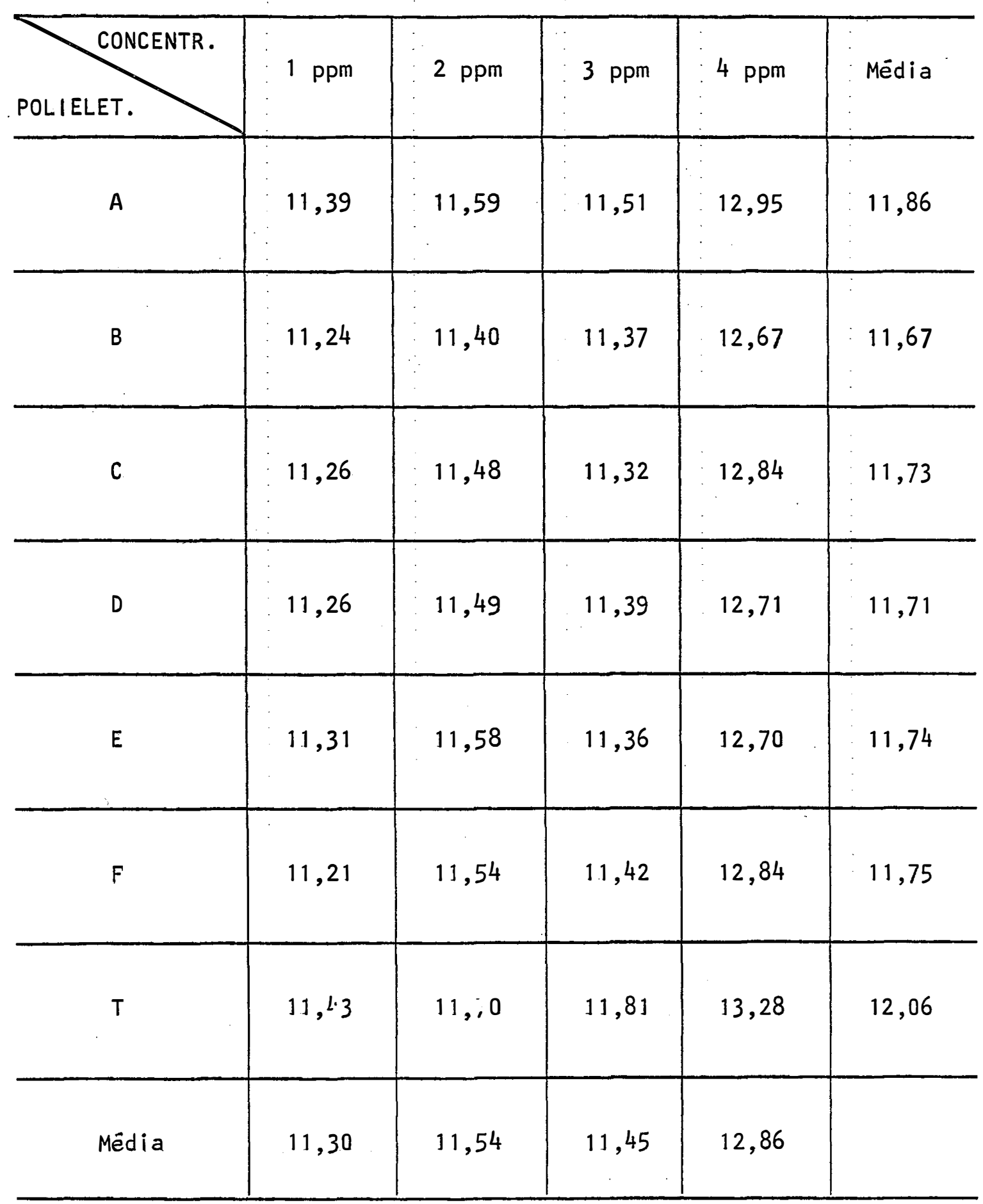




\begin{tabular}{l|l|l|l|l|l}
\hline CONCENTR. & $1 \mathrm{ppm}$ & $2 \mathrm{ppm}$ & $3 \mathrm{ppm}$ & $4 \mathrm{ppm}$ & Mëdia \\
\hline POLIELET. & 85,21 & 79,12 & 83,02 & 87,69 & 83,76 \\
\hline B & 85,22 & 79,17 & 82,81 & 85,11 & 83,08 \\
\hline C & 84,24 & 79,43 & 82,67 & 87,96 & 83,57 \\
\hline D & 85,19 & 79,63 & 82,84 & 87,36 & 83,75 \\
\hline Mëdia & 85,08 & 79,43 & 83,54 & 87,44 & 84,21 \\
\hline F & 85,33 & 79,20 & 82,50 & 87,92 & 83,74 \\
\hline & 85,23 & 79,89 & 83,43 & 88,29 & 85,00 \\
\hline & & 79,55 & 87,56 & 87,71 & \\
\hline
\end{tabular}




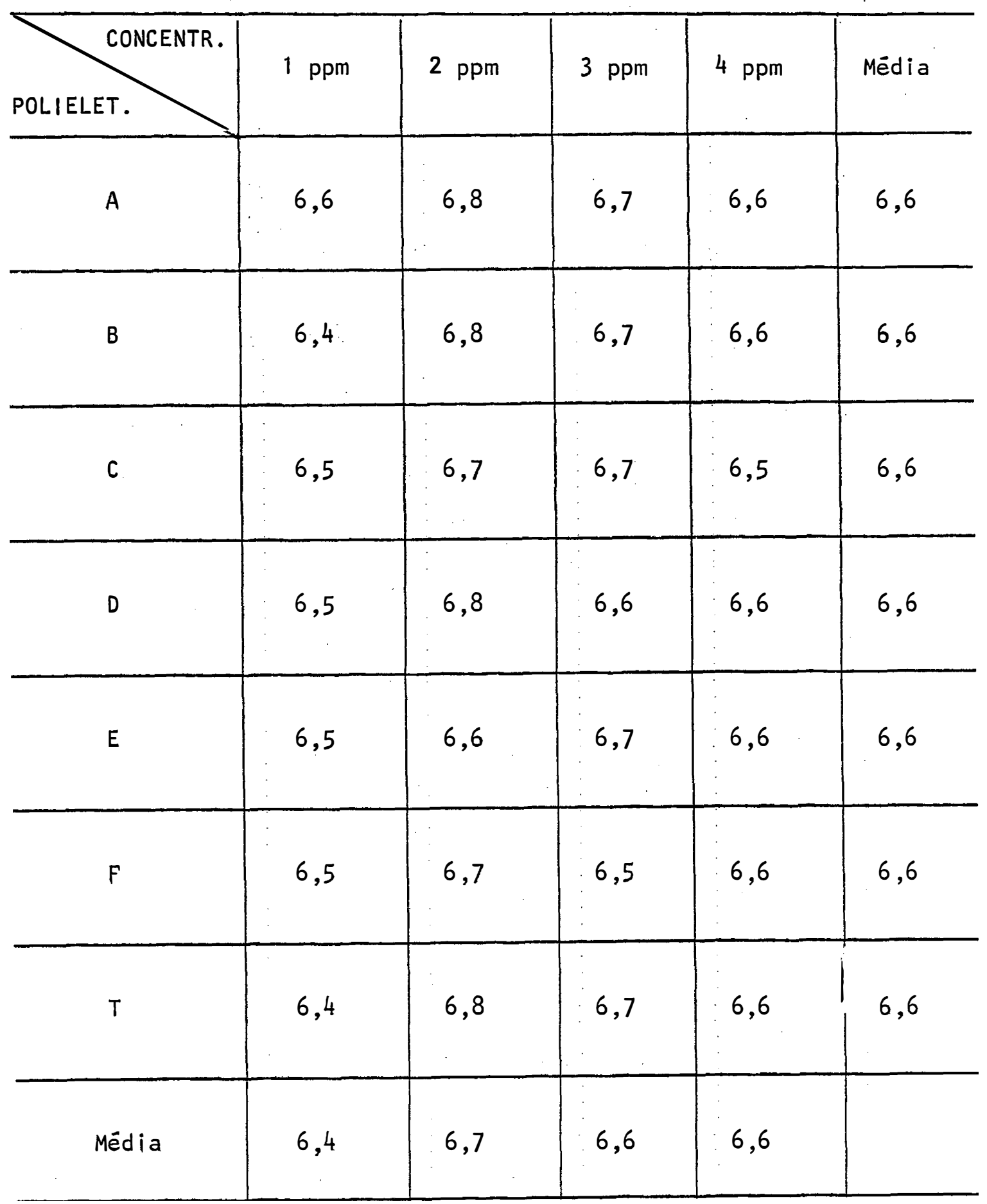




\begin{tabular}{l|l|l|l|l|l}
\hline CONCENTR. & $1 \mathrm{ppm}$ & $2 \mathrm{ppm}$ & $3 \mathrm{ppm}$ & $4 \mathrm{ppm}$ & Médi.a \\
\hline POLIELET. & 0,52 & 0,59 & 0,57 & 0,53 & 0,55 \\
\hline B & 0,52 & 0,58 & 0,57 & 0,53 & 0,55 \\
\hline C & 0,53 & 0,57 & 0,56 & 0,52 & 0,55 \\
\hline D & 0,53 & 0,57 & 0,57 & 0,51 & 0,54 \\
\hline Média & 0,53 & 0,58 & 0,57 & 0,52 & 0,56 \\
\hline F & 0,52 & 0,59 & 0,57 & 0,52 & 0,55 \\
\hline & 0,53 & 0,58 & 0,57 & 0,52 & 0,55 \\
\hline
\end{tabular}


TRATAMENTO - CaO

PARAMETRO - COr ICUMSA

$(*)$

\begin{tabular}{|c|c|c|c|c|c|}
\hline CONCE & $1 \mathrm{ppm}$ & $2 \mathrm{ppm}$ & $3 \mathrm{ppm}$ & $4 \mathrm{ppm}$ & Mëdia \\
\hline A & 150 & 127 & 119 & 119 & 129 \\
\hline B & 142 & 122 & 123 & 120 & 127 \\
\hline C & 141 & 122 & 120 & 119 & 126 \\
\hline D & 144 & 121 & 111 & 123 & 125 \\
\hline$E$ & 143 & 118 & 119 & 119 & 124 \\
\hline$F$ & 142 & 127 & 121 & 127 & 129 \\
\hline$T$ & 146 & 131 & 118 & 126 & 130 \\
\hline Mếdia & 144 & 124 & 119 & 122 & \\
\hline
\end{tabular}

(*). Dados transformados em raiz de $x+\theta$ 
TRATAMENTOS - CaO

PARĀMETRO - Turbidez

$(*)$

\begin{tabular}{l|l|l|l|l|l}
\hline CONCENTR. & $1 \mathrm{ppm}$ & $2 \mathrm{ppm}$ & $3 \mathrm{ppm}$ & $4 \mathrm{ppm}$ & Mëdia \\
\hline A & 126 & 96 & 106 & 166 & 123 \\
\hline B & 127 & 93 & 93 & 174 & 122 \\
\hline C & 132 & 98 & 94 & 159 & 121 \\
\hline D & 132 & 99 & 104 & 176 & 128 \\
\hline Mëdia & 128 & 93 & 100 & 169 & 125 \\
\hline F & 125 & 100 & 104 & 170 & 118 \\
\hline & 131 & 83 & 97 & 163 & 179 \\
\hline
\end{tabular}

(*) Dados transformados em raiz de $x+\theta$ 


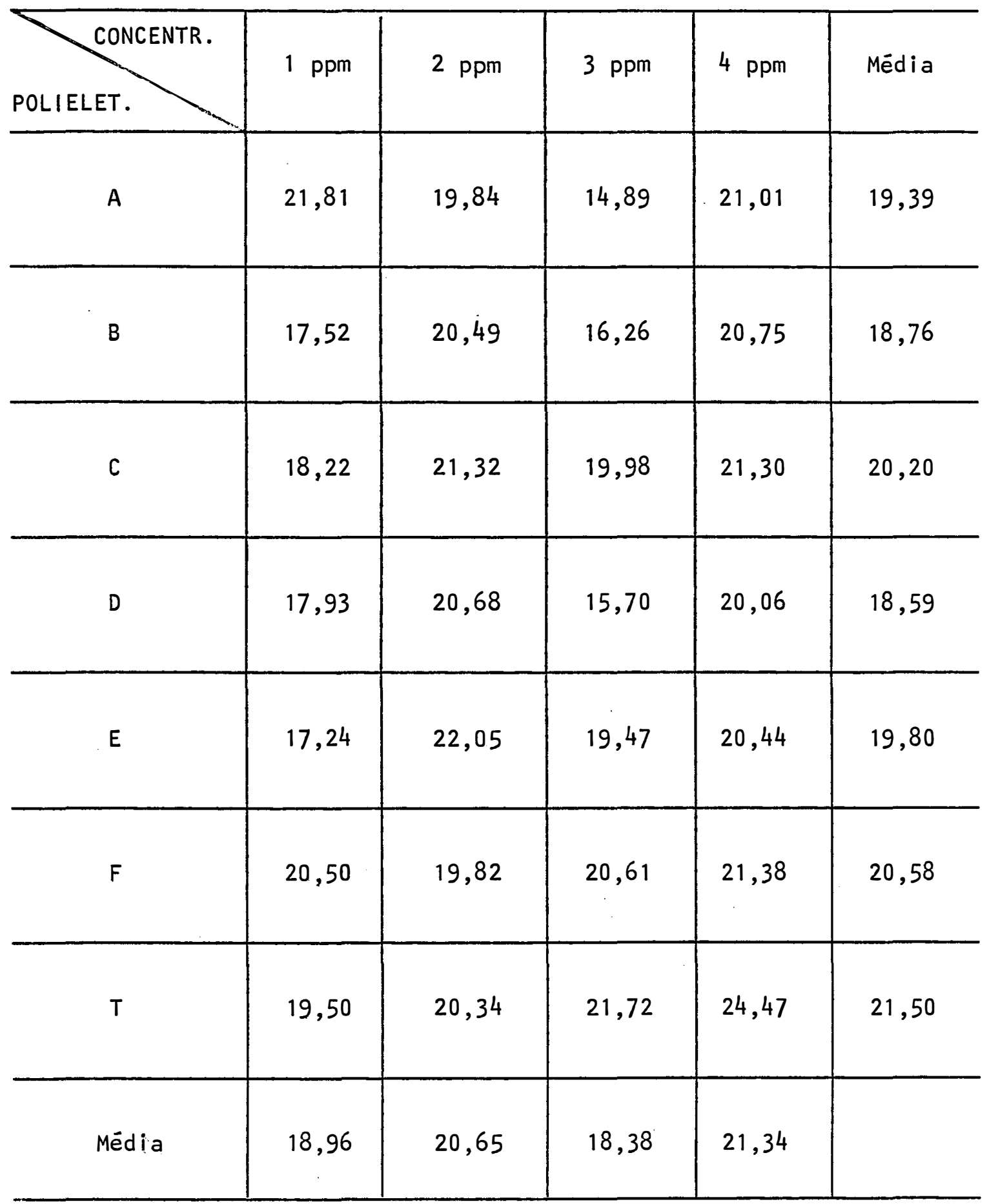




\section{DISCUSSÃO}

Os resultados obtidos na parte experimental foram tratados dentro de uma matriz estatỉstica aplicável a blocos inteiramente casualizados, onde os testes para avali ação dos níveis de significância das diferenças entre os re sultados, a $1 \%$ e $5 \%$, seguiram os modelos da análise de varí ância através do teste de $\mathbf{F}$ e teste de Tukey.

Com base nisto obtiveram-se as seguintes inter pretações:

\subsection{Caldo Sulfitado e Calleado}

\section{A) $B R I X$}

Dentro do que foi absorvido através da literatura, os trabaihos que relatam principalmente testes de $\underline{e}$ ficiência com polieletrólitos, não fázem da determinação do brix isolad-mente um elemento de real valor no julgamento da clarificação. Entretanto, este é um dado que está relaciona do à avalíação da pureza e, por consequência, em uma determinada circunstância pode vir a ser um fator de contribui 
ção para aquele fim.

O comportamento dos polieletrólitos e da te $\underline{s}$ temunha ( $T$ ) não apresentou diferenças significativas entre si. Porêm, em relação às concentraçōes utilizadas dentro de cada polieletrólito, a correspondente a 4 ppm mostrou-se $1 \underline{i}$ geiramente melhor do que as demais. Este fenômeno pode ser justificâvel, considerando que a maior concentraçāo utiliza da, 4 ppm, provavelmente nas circunstâncias quimicas do ca $\underline{1}$ do apresentado, apresentou, atravês de uma rede mais densa de sítios ativos, um maior potencial na eliminação de impurezas, o que pcr consequência, provoca matematicamente um aumento na concentração de compostos solûveis no caldo clarificado.

\section{B) $\mathrm{POL}$}

' Na mesma situação do brix, em relação aos tra balhos revisados, a pol não é colocada em um patamar de des taque. Entretanto, aparece de uma forma mais indireta como componente que ê do cálculo do coeficiente de pureza.

A anı́lise estatística mostrou que não houve diferença significativa entre os polieletrólitos e em relação à testemunha. Por outro lado, como se viu no item ante rior, e que poderia prematuramente servir como uma janela não estìmativa, mas sim indicativa, a concentração de 4 ppm 
dentro de cada polieletrôlito mostrou-se ligeiramente me1hor do que as demais, pois a pol seria a concentração de sacarose, que tambêm ê um sôlido solüvel.

\section{c) PIUREZA}

Embora nâo seja um critério ideal para se a valiar a eficiência da clarificaçāo, a avaliação da pureza serviu para dar indicaçōes do comportamento dos polieletró litos na investigação deste indicador de qualidade.

Sendo a pureza uma resposta matemática ao equacionamento dos parâmetros brix e pol, era de se esperar que sua avaliação não fugisse ao que esses parâmetros mostraram de forma consonante.E a anälise estatística realmen te ratifica isto, ou seja, entre os comportamentos dos polieletrólitos não se verificaram diferenças significativas, ' e entre as concentraçōes utilizadas dentro de cada polieletrólito aquela correspondente a 4 ppm se mostrou ligeiramen te melhor em relação às demais.

\section{D) $\mathrm{PH}$}

Neste ítem, ficou patente que os efeitos pro duzidos pelos polieletrólitos e pelas concentrações, nāo apresentaram diferenças significativas entre si e nem em re 
1ação à testemunha.

A concentração de polieletrólitos não modifi ca a concentração hidrogeniônica do meio.

\section{E) CINZAS}

Analisando as respostas do modelo estatístico aplicado, observa-se que o comportamento dos polieletró litos dentro das concentrações utilizadas não apresentou diferença significativa, embora a testemunha acusasse sempre uma concentração de cinzas ligeiramente maior do que as demais. Por outro ângulo, a anālise também mostrou uma significativa diferença de atuação entre as concentrações utî lizadas dentro de cada polieletrólito, e aquela correspon dente a 4 ppm se mostrou melhor na remoção de cinzas em re lação às outras concentrações. Entretanto, na verdade esse teor de cinzas, em relação ao caldo original, cresce na fai xa de $20 \%$, devido, provavelmente, à presença do cálcio oriundo da operação de caleagem. 


\section{F) $\mathrm{COR}$}

Com base na literatura consultada, esta determinação ê a mais utilizada e destacada como referência para se avaliar a eficiência dos polieletrólitos na clarifí cação. Mesmo porque, é através da eliminação de pigmentos, ferro, e outros compostos coloridos, que o caldo tende a se apresentar mais claro e brilhante. A cor, quanto menor, àc $\underline{u}$ sa a. melhor eficâcia do tratamento.

Neste Indice de qualidade, a diferença entre os efeitos produzidos pelos polieletrổitos não existiu a nível significativo, porém o polieletrólito $F$ apresentou uma performance ligeiramente melhor do que os demais, enquan to que a testemunha apresentou uma eficiência pior em relação aos outros, o que evidencia no principal parâmetro de a valiação a vantagem no uso dos auxiliares de decantação.

Estudando-se as variações produzidas pelas concentrações dentro de cada polieletrólito, verificou- se que 4 ppm alcançou um resultado melhor do que as outras concentrações utilizadas no trabalho. Acredita-se que isto se ja motivado pela maior disponibilidade de sítios ativos pa ra adsorção de impurezas que a maior concentração pode vir a impor ao meio. 


\section{G) TURBIDEZ}

Embora a turbidez nāo tenha o mesmo destaque da cor como referencial da eficiência de clarificação, esta grandeza também é importante para alicerçar as informações sobre as respostas dos polieletrólitos no trabalho da clari ficação. Aqui, não se verificou de maneira significativa di ferença entre os polieletrólitos dentro das concentrações $\underline{u}$ tilizadas. Porém, analisando-se os efeitos das concentrações dentro de cada polieletrólito, nota-se que a concentra ção de 3 ppm se mostrou mais eficiente, enquanto a de 4 ppm esteve mais ligada às taxas maiores de turbidez. 0 fato leva a pensar que poderia existir, no caso de cada caldo, um ponto ideal de concentração de polieletrólitos a ser utí lizado para diminuir a cor e que, a partir deste ponto, o indice de turbidez cresceria. Acredita-se que este ponto es taria entre 3 e 4 ppm.

\section{H) \% DECANTAÇÃO}

Este é outro parâmetro que a literatura, no geral, destaca como um referencial importante.

Os resultados mostraram que não se verificou diferença significativa entre os polieletrólitos e nem des ses em relação à testemunha, notando-se apenas uma tendên- 
cia da testemunha em apresentar um percentual médio ligeira mente maior.

No tocante ao efeito das concentraçōes dentro de cada polieletrólito, a correspondente a 4 ppm foi significativamente mais eficaz do que as outras.

\subsection{Caldo Caleado}

\section{A) BRIX}

0 tratamento dos resultados deixou patente que entre os polieletrólitos nas diversas concentraçōes não houve diferença de comportamento. Quando a análise se proje ta sobre o efeito das concentraçōes dentro.de cada poliele trólito, ela indica que há uma significativa diferença entre a eficiência dessas concentraçōes, sendo que a correspondente a 4 ppm se mostra melhor do que as outras. Acredi ta-se que a justificativa seria a mesma apresentada na aná lise dos resultados de brix para o caldo sulfitado e caleado. 


\section{B) $\mathrm{POL}$}

Verificou-se nesta anâlise, que entre os po lieletrólitos nas värias concentraçōes, não existiu diferen ça significativa. Entretanto, estudando-se a matriz estatís tica, ela mostra que nas concentrações dentro de cada polie letrólito a correspondente a 4 ppm se mostra melhor do que as demais.

\section{c) PUREZA}

Este indice analitico deve refletir teorica mente as posturas consonantes das avaliações feitas para brix e pol. E realmente a prâtica confirma o modelo teórico. Não se verificou diferenças significativas de comporta mento entre os diversos polieletrólitos, enquanto nas con centrações dentro de cada polieletrólito a correspondente a 4 ppm se mostrou ligeiramente melhor do que as demais.

\section{D) $\mathrm{PH}$}

Aqui, verificou-se que não houve diferença significativa entre as respostas dos polieletrólitos e nem entre as concentrações dentro de cada polieletrölito. Mesmo porque não existiria, na interpretação do autor, implicação dos polî 
meros sobre a disponibilidade de Ions hidrônios no meio.

\section{E) CINZAS}

Verificou-se aqui que nāo houve diferença significativa entre os polieletrólitos, sendo que a testemu nha apresentou níveis de cinzas ligeiramente maior. Por ou tro lado, analisando-se os efeitos das concentrações em ca da polieletrólito, observa-se uma resposta melhor da concen tração correspondente a $4 \mathrm{ppm}$.

Convém também ressaltar que, em relação ao caldo original, o teor de cinzas cresceu em torno de $25 \%$, provavelmente devido à presença do câlcio introduzido no sis tema através da operação de caleagem.

\section{F) $\mathrm{COR}$}

As concentraçōes dentro de cada polieletrôli to apresentaram diferenças nos níveis de eficiência de atua ção. As mais altas; 3 e 4 ppm, mostraram-se mais eficazes. Acredita-se que, provavelmente, is to seja motivado pelo fato de que as concentraçōes maiores podem determinar um es pectro maior na disponibilidade de sitios ativos para auxiliarem a promover a decantação e, por conseguinte, uma melhor clarificação. 
Entre os polieletrólitos não se verificaram diferenças significativas de comportamento, estando, entre tanto, a testemunha acusando uma eficiência ligeiramente aquém das demais, o que atesta uma pequena vantagem na utili zação destes auxiliares de clarificação.

\section{G) TURBIDEZ}

A análise não revelou diferenças significat vas entre os polieletrólitos. Entretanto, mostrou que estas existem quáando se estuda o efeito das concentrações dentro de cada um desses auxiliares de clarificação. Ficou patente que as concentrações de 2 e 3 ppm apresentaram uma performance melhor, enquanto que a de $4 \mathrm{ppm}$ apresentou uma eficí ência menor. Acredita-se que a justificativa seja a mesma postulada quando no enfoque do parâmetro turbidez no caldo sulfitado e caleado. Esta justificativa é inclusive respaldada pela afirmação de CHEN, RAUH e ARELlANO (1983), onde esses autores postulam que o aumento da dosagem acima do re querido pode provocar decréscimo nos resultados de determinados parâmetros. 


\section{H) \% DECANTAÇÃO}

Conforme jầ foi dito, este é um ítem que se destaca como referencial importante na avaliação da eficiên cia dos polieletrólitos.

Não foi verificada aqui, diferença entre as atuações dos polieletrôlitos e também não houve entre as concentrações. Apenas uma performance ligeiramente melhor para a correspondente a 4 ppm, com níveis em média de $21,34 \%$. Isto se deve provavelmente ao fato de que a maior concentração impôs ao meio uma maior rede de sítios ativos dispo niveis de sua estrutura molecular, o que contribuiu para pro mover um nümero ligeiramente maior de efeitos de adsorção das partículas e, por conseguinte, um agregado de impurezas a ser decantado um pouco mais volumoso. 


\section{DISCUSSŌES FINAIS}

Com base no que foi lido na literatura e em função da análise dos resultados obtidos, puderam ser inseridas no contexto deste trabalho as seguintes discussões finais:

a) Os polieletrólitos estudados, de uma for ma global, não apresentam diferenças significativas entre os seus níveis de eficiência. Embora haja pequenas diferen ças de ordem de grandeza entre seus pesos moleculares, como foi visto no texto, o que seria um fator implicante na dis tinção da estrutura molecular, segundo SHEPARD (1978) e, por conseguinte, poderia vir a estabelecer diferenciaçōes no grau de adsorção de partículas, parece que, particularmente neste estudo, este tipo de fenômeno pode ter tido um grau de participação que não se fez manifestar de forma determinante. Ou então, se tivesse ocorrido casos de caldo com teores de impurezas muito maiores poderia ser que os re flexos desta teoria se manifestassem de forma mais evidente. Entretanto, isto também ficaria em um patamar de suposi ção, porque o caldo também poderia vir a trazer particulari dades a nivel intramolecular e que poderiam ser decisórias ou não no rendimento do polieletrólito, apesar das suas con 
dições de distensão da estrutura molecular. Em resumo, o que se quer colocar ê que, embora o fator distensão da cadeia do polieletrôlito possa ser um fator de influência na atuação do polímero, nem sempre a condição do caldo de cana permite que isto seja decisório, principalmente quando vis to sob um ângulo comparativo entre dois ou mais polímeros.

b) Segundo a literatura no geral, um dos te $\underline{s}$ tes mais importantes para a avaliação da eficiência seria $\underline{a}$ través do índice de cor. Pode-se verificar que embora não se patenteou em um nível significativo a diferença entre os polímeros e a testemunha, percebe-se neste ítem que a teste munha se posiciona dentro de uma escala comparativa, ligeiramente inferior da maioria dos polieletrólitos, o que de certo serve para reforçar a teoria de que mesmo de uma for ma modesta os polieletrólitos colaboram para a limpidez do caldo de cana.

c) No estudo da remoção de cinzas, a nosso ver parece que não só pela alta solubilidade que os não açú cares inorgânicos apresentam, mas também pelo volume iônico não muito grande quando comparado com impurezas de outra na tureza, pois a interação também será dependente do tamanho da partícula, segundo SHEPHARD (1978) e BERGER (1976), a atuação dos polieletrólitos nos pareceu aqui ligeiramente im 
potente diante deste contexto, ainda mais que o teor de cin zas em relação ao caldo original cresce, provavelmente deví do à presença do cálcio trazido através da operação de caleagem. Ainda assim, quando comparado com a testemunha, em bora a diferença não seja significativa, a testemunha se mostra ligeiramente aquém dos polímeros.

d) Outro indice importante na avaliação da eficiência seria o percentual de borra decantada. Aqui, cu riosamente, não se verificou diferença significativa entre os tratamentos, inclusive a testemunha. Porém, esta apresentou um percentual ligeiramente maior do que os demais, embora no tocante ao índice de cor, sua participação foi a menos eficiente. Isto indica dois caminhos conclusivos. Primeiramente, reforça o que a literatura afirma, que nem sempre o melhor indice de decantação pode estar amarrado ao menor e, por conseguinte, melhor indice de cor, até porque não só o aspecto quantitativo é que estaria envolvido, mas também o qualitativo, ou seja, não é sô importante quanto se decanta, mas também o que se decanta, pois diferentes compostos, até por determinação de seus diferentes níveis de elétrons: teriam iferentes capacidades de absor bância e, por conseguinte, diferenças para o indice de cor. Em segundo, esta modesta diferença poderia estar amarrada a um pequeno efeito de compactação, parcialmente e indireta- 
mente provocado pela presença do polímero. Assim, onde nao se verifica a sua presença, como no caso da testemunha, o bolo decantado pode vir a ter um grau de agregaçao menor e, desta forma, na proveta, esse volume aparece um pouco mais distendido, dando a impressão de ser ligeiramente maior. Na verdade, talvez fosse também interessante, e fica esta idêia para estudos posteriores correlatos que vierem a ser feitos, que também se pesasse a borra depois de seca e se analisasse seus constituintes.

e) Ficou bem definido que, no geral, o efe $\underline{i}$ to da concentração correspondente a $4 \mathrm{ppm}$ se pronunciou me lhor do que as outras. Provavelmente, sendo a maior concentração em relação as demais, ela pode fornecer ao meio uma rede molecular com maior disponibilidade de sítios de adsor ção, o que lhe abriria caminho para um performance melhor. Entretanto, como confirma CHEN (1974), isto pode ocorrer pa ra alguns tipos de caldo, mas não necessariamente com todos os tipos de caldo.

f) A realidade operacional hoje das fábricas de açücar estaria vinculada também ao iipo e qualidade da matéria-prima. Existem particularidades pertinentes a con textos regionais, têcnicos, energéticos ou até políticos no direcionamento de um programa de produção, onde segundo ST $\underline{U}$ PIELLO (1986), uma outra ou algumas variedades estariam mais identificadas com uma determinada conduta dos segmentos ci tados do que outras. O perfil da moagem atualmente nas usi- 
nas revela na entrada para processamento uma considerāvel diversificação de variedades, quer sejam próprias ou de for necedores.

CHEN (1974); MUJICA et alii (1978); MARTINEZ, IRIARTE e GONZALES (1978) consideram que este fator tambëm influencia na resposta da atuação dos polieletrölitos, assim como também as condições de processamento, con forme postula CHEN (1974). Isto significa que o estudo realizado com caldo de uma determinada fábrica, como foi o ca so, pode não dar a mesma resposta em outra, que provavelmen te estarā vivendo uma outra realidade a nível de região, condições de processamento e variedades.

Fica, portanto, a sugestão de que, para eleger entre alguns polieletrólitos oferecidos comercialmente aquele que irá atuar em sua linha fabril, o laboratório da usina deve realizar testes comparativos entre alguns desses polímeros, principalmente com caldos de cana oriundos das variedades a serem processadas pela fábrica, tanto de uma forma conjunta como tambëm de determinadas variedades isola damente. 
.90 .

\section{CONCLUSÕES}

Fundamento nos dados obtidos e nas abordagens feitas, pode-se concluir que:

a) Não existe uma diferença significativa en tre as eficiências de atuação dos polieletrólitos estudados, nas condições do experimento.

b) Todos os polieletrólitos mostraram-se me 1hores do que a testemunha em relação ao parâmetro Cor ICUMSA, o qual, juntamente com o percentual de decantação, é o mais importante parâmetro para se avaliar a eficiência da clarificação.

c) Os polieletrólitos não são eficazes na re moção das cinzas.

d) Não existiu diferença significativa entre os tratamentos, inclusive a testemunha, na avaliação compa rativa da taxa de decantação.

e) A concentração de 4 ppm foi a que se com 
portou de maneira mais eficaz.

f) Os resultados obtidos puderam retratar a comparação da eficiência dos produtos estudados, particular mente apenas para a unidade fabril em que o caldo foi cole tado, visto que, cada uma das fâbricas do universo produtor tem suas características e peculiaridades muito pró prias, tanto sob o ponto de vista agronômico como industrial. 


\section{REFERENCIAS BIBLIOGRÄFICAS}

ALMEIDA, J.R. de. Princípios gerais da fabricação do açūcar de cana. Piracicaba, Centro Acadêmico Luiz de Quei roz, 1944 . 228p.

ASSOCIATION OF HAWAIIAN SUGAR TECHNOLOGISTS. Sugar cane. factory analytical control. 6. Honolulu, John H. Payne, 1968. p. 190 .

BAIKOW, V.E. Manufacture and refining of raw cane sugar. Amsterdam, Elsevier, 1967. 453p.

BALCH, R.T. Los lîpidos de 1 a caña de azucar. In: HONIG, P. Principios de tecnologia azucarera. México, Continental, 19.69. 1,7. p. 173-187.

BENNETT, M.C. The physical nature and behaviour of cane su gar juice. International Sugar Journal, Bucks, 59(703): 176-178, julho 1957 . 
BENNETT, M.C. Flocculation process in sugar manufacture. Jamaican Association of Sugar Technologists Journal, Man devilie, 35: 101-106, 1975 .

BERGER, P.D. Surfactants and surface activity in sugar manufacturing. Sugar Technology Reviews, Amesterdam, $\underline{3}(1)$ : 241-273, jan. 1976 .

BOSE, S.; GUPTA, K.C.; MUKHERJEE, S. Studies on the use of flocculating agents during sugar cane juice clarification. In: ANN. CONV. SUGAR TECHNOLOGISTS ASSOCIATION OF INDIA, New Delhi, 1976. Proceedings. New Delhi, Sugar Technologists Association of India, 1976, p. 61-66.

BOTElHo, J. Colóides e adsorção. Brasil Açucareiro, Rio de Janeiro, 37(6): 84-86, junho 1951.

BROWNE, C.A. \& ZERBAN, F.W. Phisical and chemical methods of sugar analysis. 3a edição. New York, Wiley, 1941. $1353 \mathrm{p}$.

CARDENAS, L.G. \& ARMAS, A.L. Algunos aspectos de1 pape1 de los aminoácidos en la reacción amino-carbonilica. Revista del consejo cientifico del azucar y derivados de la Universidade Central de Las Villas, Santa Clara. 1977. 
CHEN, J.C.P. Polymers in cane juice clarification. Sugar Journal, New Orleans, 40(5): 61-69, oct. 1977.

CHEN, J.C.P.; RAUH, J.S.; ARELlANO, P.R. A practical method of evaluating polymer flocculants in factory operations. Journal of the American Society of Sugar Cane Technolo-. gists, Baton Rouge, 2: 72-77, June 1983.

CHEN, W. \& CHEN, C.H. Applications of the polymeric electrolyte for improving the basic clarification mechanism in the defecation of cane juice. Rpt Taiwan Sugar Expt. Sta.., (30): 103-118, jun. 1963.

CHINLOY, T. Extraneous matte $r$ in cane. Jamaican Association of Sugar Technologists Journal, Mandeville, 33: 111116,1972 .

DELGADO, A.A. Estudo de duas bentonitas na clarificação do caldo de cana pelo processo de defecação simples. Piracicaba, 1969. 56p. (Doutorado - Escola Superior de Agricultura "Luiz de Queiroz"-USP). 
DELGADO, A.A. Clarification of the juice from umburned and burned canes. In: CONGRESS OF THE INTERNATIONAL SOCIETY SUGAR CANE TECHNOLOGISTS, 16, São Paulo, 1977. Procee dings. São Paulo Impres, 1978. p. 3023-3030.

DOW CHEMICAL COMPANY. Separan polymers. Midland, 5. ed., 1975. 28p.

EL-KADER, A.A. Comparative study on various constituints of sugarcane juice affecting settlings in the sulphitati on and phosphatation processes. Sugar Journal, New Orleans, $\underline{45}(12):$ 5-8, May 1983.

GHASH, S.K. Clarification of cane juice with a new flocculating agent. Indian Sugar, New Delhi, $\underline{5}(4):$ 637-642, 1955 .

GIL, W.B.; BARRON, E.V.; ZAFRA, L.C.; PEREZ, N.G.; GONZALES, J.B. Analisis de algunos factores que inciden en la com posicion de zus materias extrañas. Centro Azucar, Santa C1ara, 13(2): 60-68, abr/jun. 1986 .

GOMES, F.P. Curso de estatística experimental. 11. Piracicaba, Nobe1, 1985. 466p. 
HERNANDEZ, M.T.; DAUVAL, C.; PEREZ, M.E. Acción de1 L. mesenteroides y otros microorganismos sobre los componentes del jugo de caña. Centro Azucar, Santa Clara, $\underline{5}(1)$ : 69-85, ene./abr. 1978 .

HONIG, P. Tecnologia quimica del proceso de purificación. In: HONIG, P. Princípios de tecnologia azucarera. Méxi co, Continental, 1969. 1,12. p. 423-434.

JENKINS, G.H. Clarification procedure and reactions. In: JENKINS, G.H. Introduction to cane sugar technology. Amsterdam, Elsevier, 1966. p. 172-188.

JOHARY, P.C. Some observations on the use of polymers in cane juice clarification and settling-sedimentation characteristics of magnafloc LT-27, a comparative study. Indian Sugar, New Delhi, 31(11): 783-788, Feb. 1982.

KOZIAVKIN, A.P.; ODORODKO, N.J.; BOBROVNIK, L.D. Influencia del sulfito de sodio en la efectividad de la purificación de las soluciones azucaradas roncentradas. Centro Azucar, Santa Clara, 10(2): 35-4r, mayo/ago. 1983.

LEE, C. Clarification with polyelectrolytes. Sugar, New York, 48(11): 33-36, nov. 1953. 
MARCHES, J. Clarificación de los jugos de cana por medio del procedimento de sulfitación. In: HONIG, P. Principios de tecnologia azucarera. México, Continental, 1969. 1,15 . p. 503-560.

MARON, S.H. \& PRUTTON, C.F. Colloids. In: MARON, S.H. \& PRUTTON, C.F. Principles of physical chemistry. 3 ed. New York, Macmillan, 1965. cap. 8. p. 232-244.

MARTIN, L.F. Los äcidos organicos no nitrogenados de la ca ña de azucar. In: HONIG, P. Principios de tecnologia azucarera. Mëxico, Continental, 1969. 1,4. p. 131-153.

MOSPAN, N.; ARTILES, J.; MARTinez, N.; VARGAS, N. Me todolo gia para el procesamiento de los resultados experimentales y determinacion de la velocidad de sedimentación. Centro Azucar, Santa Clara, 11(1): 61-70, ene./abr. 1984.

MUJICA, R.D.; PAREDES, A.M.; IRIARTE, A.D. Estudio compara tivo de 22 variedades de caña de azucar en la costa norte de Villa Clara. Centro Azucar, Santa Clara, $\underline{5}(1): 1-$ 18 , ene./abr. 1978 .

MULLINS, R.T. \& ROACH, B.T. Genetic origins of ash in sugar cane juice. Sugar Journal, New Orleans, 48(8): 16-20, jan. 1986. 
OLIVEIRA, E.R. de. A cal na indústria do açücar. In: REUNIĀO ABERTA DA INDUSTRIA DA CAL, 3. São Paulo, 1978. Anais. São Paulo, agosto, 1979. p. 125-146.

PAYNE, G.W. Condiciones fisicas y tecnicas para la fabrica cion de azucar. In: HONIG, P. Principios de tecnologia azucarera. México, Continental, 1969, 1,11. p. 379-419.

PAYNE, J.H. Reacciones fundamentales del proceso de clarificacion. In: HONIG, P. Principios de tecnologia azucarera. México, Continenta1, 1969, 1,13. p. 437-463.

RAHA, A.C. Kinetics of the sedimentation process of cane juice. In: CONGRESS OF THE INTERNATIONAL SOCIETY SUGAR CANE TECHNOLOGISTS, 16. São Paulo, 1977. Proceedings. São Paulo Impres, 1978. p. 2859-2872.

RAMIREZ, R. Trials with separan AP 30 at Central Guänica. Paper presented to the Ann. Meeting Assoc. Técn. Azuc. Puerto Rico, s.1., s.ed., s.d., 1959. Apud iilternational Sugar Journal, Bucks, p. 190, jul. 1960. (Resumo) 
RAO, K.H. \& SINHA, K.P. Studies on the use of flocculating agents during sugar cane juice clarification by the sulphitation process. In: ANN. CONV. SUGAR TECHNOLOGYST AS SOCIATION OF INDIA, 42. New Delhi, 1978. Proceedings. New Delhi, Sugar Technologists Assoc. of India, 1978. p. 47-57.

SHARMA, S.C.; JOHARY, P.C.; RAO, G.S.C. Some observations on the chemical composition of the cane juices of different promising varieties grown in North Bihar conditions and their clarification characteristics. Indian Sugar, New De1hi, 29(3): 141-147, junho 1979.

SHEPHARD, G.S. Some factors affecting the performance of polyacrylamide flocculants in juice clarification. In : ANNU. CONGR. SOUTH AFRICAN SUGAR TECHNOLOGISTS ASSOCIA TION, 52, Mount Edgecombe, 1978. Proceedings. Mount Ed gecombe, South African Sugar Technologists Assoc., 1978. p. $106-112$.

SILVA, J.F. da \& SILVA, E. da. Eficiência de auxiliares de clarificação. Boletim Técnico Copersucax, São Paulo, (3) : 12-13, julho 1976 . 
SLOANE, G.E. Application of polielectrolytes in Hawaiian raw sugar factories. In: HAWAIIAN SUGAR TECHNOLOGY MEETING, 14. Hawaii, 1955. Annual report. Honolulu, Aiea, 1956. p: 59-61.

SPENCER, G.L. \& MEADE, G.P. Manual del azucar de caña. 9 . ed. Barcelona, Montaner y Simon S.A., 1967. 940p.

STUPIELlo, J.P. Variedades; ótica agrícola e ótica industrial. STAB, Piracicaba, 5(1): 44-50, set./out. 1986.

THIBAUT, J.H. Polielectrolyte for sugar juice clarification. Sugar, New York, 16(10): 28-30, out. 1954 .

VAN OLPHEN, H. Macromolecular compounds. In: VAN OLPHEN, H. An introduction to clay colloid chemistry. New York, Interscience, 1963. $301 \mathrm{p}$.

WHAYMAN, E. \& CRESS, O.L. Mechanistic studies of cane mud flocculation. In: CONGRESS OF THE INTERNATIONAL SOCIETY SUGAR CANE TECHNOLOGISTS, 15. Durban, 1974. Proceedings. Durban, Hayne \& Gibson, 1974. p. 1175-1182. 
ZARRALUQUT, O.N.; MONTERO, G.N.; RODRIGUEZ, M.C.; ClAVELO, H.E. Consideraciones sobre la remoción de sustancias co lorantes y coloidalmente dispersas y su dependencia de los parâmetros del primer tratamiento químico en el proceso de refinacion. Centro Azucar, Santa Clara, 11 (1): 105-112, ene./abr. 1984 .

ZUMALACÁRREGUI, L.; SANTANA, R.; GUERRA, J. Anālisis de 1a precipitación en jugos de caña simulados. Centro Azucar, Santa Clara, 11(1): 19-34, ene./abr. 1984. 